\title{
Glucose supplementation stimulates peripheral branched-chain amino acid catabolism in lactating dairy cows during essential amino acid infusions
}

\author{
K. Nichols, ${ }^{*}$ J. J. M. Kim, ${ }^{*}$ M. Carson, $†$ J. A. Metcalf, $\dagger$ J. P. Cant, ${ }^{*}$ and J. Doelman ${ }^{1}$ \\ *Department of Animal Biosciences, University of Guelph, Ontario, N1G 2W1 Canada \\ †Trouw Nutrition Agresearch Canada, Guelph, Ontario, N1G 4T2 Canada
}

\begin{abstract}
To determine how glucose modulates protein synthesis when essential AA are in abundant supply, 5 early-lactation, rumen-fistulated Holstein dairy cows were fed a diet containing $6.95 \mathrm{MJ} / \mathrm{kg}$ of net energy for lactation and $12.4 \%$ crude protein and abomasally infused for $5 \mathrm{~d}$ with saline, 844 or $1,126 \mathrm{~g} / \mathrm{d}$ of a complete essential AA mix, with and without the inclusion of $1,000 \mathrm{~g} / \mathrm{d}$ of glucose, in a $5 \times 5$ Latin square design. Infusion of essential AA increased milk yield by $4.1 \mathrm{~kg} / \mathrm{d}$, milk protein by $256 \mathrm{~g} / \mathrm{d}$, milk fat by $95 \mathrm{~g} / \mathrm{d}$, and milk urea nitrogen by $70 \%$ compared with saline, with no differences between the level of essential AA infusion. The addition of glucose to essential AA infusate did not stimulate milk protein yield or concentration, but reduced milk urea nitrogen by $17 \%$ and decreased milk fat yield. Arterial concentrations of total essential AA increased 3- to 4-fold, mammary clearance decreased $61 \%$, and mammary uptake of essential AA increased $65 \%$ in response to essential AA infusion. Arterial branched-chain AA concentrations declined 29\% in response to glucose and mammary clearance increased $48 \%$, but mammary AA uptake was unchanged. Essential AA infusion increased plasma 3-methylhistidine by $50 \%$ and reduced muscle branched-chain $\alpha$-keto acid dehydrogenase kinase abundance by $14 \%$, indicating stimulation of muscle protein turnover and branchedchain AA catabolism, respectively. Glucose had no further effect on muscle branched-chain $\alpha$-keto acid dehydrogenase kinase abundance but decreased mRNA expression of branched chain aminotransferase 1. Lack of further increases in plasma 3-methylhistidine or greater stimulation of muscle branched-chain AA catabolism indicates that muscle protein degradation was unchanged with glucose but that accretion may have been stimulated. The decrease in circulating branched-
\end{abstract}

Received June 5, 2015

Accepted October 13, 2015.

${ }^{1}$ Corresponding author: john.doelman@nutreco.ca chain AA concentrations and nitrogen excretion in response to glucose suggests that surplus essential AA were redirected to peripheral, extra-mammary tissues.

Key words: amino acid, glucose, protein synthesis, mammary, muscle

\section{INTRODUCTION}

Milk protein yield from dairy cows can be manipulated by both protein and energy supply, but these dietary components appear to exert different effects on whole-body metabolism and AA partitioning. It is well known that more than $50 \%$ of dietary protein may not be captured in milk protein; most of the $\mathrm{N}$ loss occurs at the postabsorptive level, where AA not used for milk protein are partitioned into skeletal muscle, other labile protein pools, or catabolic pathways (Hanigan et al., 1997, 1998a). Increased mammary uptake and use of AA for milk protein synthesis would improve efficiency of use, lowering ingredient cost and reducing environmental $\mathrm{N}$ loss. Because protein synthesis is an energy-demanding process, increasing energy supply to the mammary gland may enhance milk protein yield and efficiency of $\mathrm{N}$ capture. Many groups have observed positive effects of energy on lactation performance and postabsorptive $\mathrm{N}$ efficiency. Cows fed 16.6 and $14.6 \%$ $\mathrm{CP}$ diets, both with 6.7 MJ of $\mathrm{NE}_{\mathrm{L}} / \mathrm{kg}$ of DM, produced 220 and $160 \mathrm{~g} / \mathrm{d}$ more milk protein, respectively, than cows fed $5.9 \mathrm{MJ} / \mathrm{kg}$ (Rius et al., 2010). Efficiency of conversion of absorbed $\mathrm{N}$ into milk $\mathrm{N}$ increased when glucose was added to abomasal casein infusions (Clark et al., 1977). Raggio et al. (2006a,b) stimulated milk protein synthesis with infusions of casein into the duodenum or propionate into the rumen, with a greater increase observed for casein infusion and an additive effect when the 2 were infused together. The stimulatory effect of glucose or glucose precursors on AA partitioning to the mammary glands may be mediated in part by insulin, as shown from the increased mammary blood flow and milk protein yield response to a hyperinsulinemic-euglycemic clamp (Griinari et al., 1997; Mackle et al., 2000). 
Although several studies report positive milk yield responses to glucose or glucose precursor infusions (Hurtaud et al., 2000; Rulquin et al., 2004; Raggio et al., 2006a,b), in some instances glucose did not stimulate milk protein yield (Clark et al., 1977; Vanhatalo et al., 2003a,b; Curtis et al., 2014). It is possible that EAA supply to the mammary gland limits the effect of postruminal glucose on milk protein yield. Glucose infusions have been shown to decrease plasma concentrations of EAA, primarily the branched-chain AA (BCAA; Hurtaud et al., 1998, 2000; Lemosquet et al., 2004). In response to propionate + casein infusion, mammary uptake of EAA increased, but during propionate infusion alone, NEAA uptake increased more than EAA uptake (Raggio et al., 2006a), probably because EAA were in short supply. Supply of energy precursors can alter the profile of mammary uptake depending on the concomitant supply of EAA available to the gland. Additionally, if insulin is mediating the protein synthetic response at the mammary glands, it is possible that variation in the insulin response to glucose results in inconsistent effects on milk protein yield (Rulquin et al., 2004). Furthermore, the reductions in plasma EAA concentrations and $\mathrm{N}$ excretion have been interpreted to suggest that glucose partitions AA toward extramammary tissues, such as skeletal muscle (Clark et al., 1977; Curtis et al., 2014).

The objective of this study was to determine the effects of supplemental glucose on milk protein production in lactating dairy cows during EAA infusion. A high level of AA infusion, in comparison with previous studies (Metcalf et al., 1996; Doepel and Lapierre, 2010; Galindo et al., 2011; Doelman et al., 2015a,b), was used to ensure that AA would not limit milk protein yield when glucose was infused. In previous experiments, we infused EAA in equivalent amounts found in $1 \mathrm{~kg} / \mathrm{d}$ of casein into cows fed a low-protein diet, and observed an average increase of $164 \mathrm{~g} / \mathrm{d}$ in milk protein yield compared with a saline control (Doelman et al., 2015a,b). In the current experiment, we applied the same infusion model with 1.5 and 2 times the EAA supply.

\section{MATERIALS AND METHODS}

\section{Experimental Protocol and Sampling}

All experimental procedures were approved by the Animal Care and Use Committee at Trouw Nutrition Agresearch, adhering to guidelines set forth by the Canadian Council on Animal Care (2009). Five rumenfistulated, multiparous ( $2.4 \pm 0.5$ lactations; second lactation $\mathrm{n}=3$, third lactation $\mathrm{n}=2$ ) Holstein cows producing an average of $33.0 \mathrm{~kg} / \mathrm{d}$ at $78 \pm 13$ DIM and $576 \pm 70.3 \mathrm{~kg}$ of BW were randomly assigned to a $5 \times$
5 Latin square design in which each period consisted of a 5 -d continuous abomasal infusion followed by $2 \mathrm{~d}$ of rest. Cows were housed in tie stalls with individual free access to water and milked twice daily at 0500 and 1600 h. A TMR (Table 1) was formulated to provide an $\mathrm{NE}_{\mathrm{L}}$ of $6.94 \mathrm{MJ} / \mathrm{kg}$ of $\mathrm{DM}$ and $12 \% \mathrm{CP}$ to meet 100 and $70 \%$ of $\mathrm{NE}_{\mathrm{L}}$ and $\mathrm{MP}$ target requirements, respectively. Production targets were $32.5 \mathrm{~kg} / \mathrm{d}$ of milk yield consisting of $3.8 \%$ fat and $2.8 \%$ protein. Cows were acclimated to the diet for $14 \mathrm{~d}$ before the start of the experiment and were fed once daily at $0700 \mathrm{~h}$ for the duration of the experiment at a fixed amount based on the daily average as calculated using the last $7 \mathrm{~d}$ of the 14-d acclimation period. Cows were weighed $2 \mathrm{~d}$ before the start of the experiment and at the end of each period. Feed refusals were measured daily and TMR samples were taken on a weekly basis, stored at $-20^{\circ} \mathrm{C}$, pooled, and subsampled for proximate analysis. Silages were monitored weekly for DM content and the TMR mix was adjusted accordingly.

Infusion lines were placed in the abomasum via the rumen cannula $1 \mathrm{~d}$ before the first experimental period and were checked daily for patency and position. Infusion treatments were $0.9 \%$ saline (SAL), or complete mixtures of EAA with the same profile and amount as found in 1,500 and 2,000 $\mathrm{g}$ of casein according to Metcalf et al. (1996), with or without the inclusion of $1 \mathrm{~kg}$ of glucose (1.5EAA, 2EAA, 1.5+GLC, and 2+GLC, respectively). Treatment solutions were prepared daily in 10-L batches and were infused using

Table 1. Ingredient and chemical composition of TMR

\begin{tabular}{lc}
\hline Component & $\begin{array}{c}\text { Content } \\
\text { (\% of DM) }\end{array}$ \\
\hline Ingredient composition & \\
Corn silage & 49.8 \\
Haylage & 17.0 \\
Corn, ground & 15.7 \\
Wheat shorts & 6.1 \\
Straw, chopped & 5.3 \\
Mixed hay & 2.6 \\
Tallow & 1.2 \\
Rumen-protected soybean meal ${ }^{1}$ & 1.1 \\
Vitamin/mineral mix ${ }^{2}$ & 1.1 \\
Urea & 0.003 \\
Nutrient analysis & \\
CP & 12.4 \\
NDF & 28.7 \\
ADF & 18.6 \\
NFC & 46.8 \\
Crude fat & 5.3 \\
Ash & 6.8 \\
Ca & 0.71 \\
P NE & MJ/kg)
\end{tabular}

${ }^{1}$ TopSoy obtained from Shur-Gain Feed Mill (St. Mary's, ON, Canada). ${ }^{2}$ Contained $42 \%$ limestone, $32 \% \mathrm{~K}, 14 \% \mathrm{Mg}, 11 \% \mathrm{Ca}, 0.3 \%$ vitamin E, $0.3 \% \mathrm{NaCl}, 0.3 \%$ Se. 
a Watson-Marlow 205U/CA multi-channel peristaltic pump (Wilmington, MA) at a rate of $6.95 \mathrm{~mL} / \mathrm{min}$, delivering 884 and $1,126 \mathrm{~g} / \mathrm{d}$ of EAA for the 1.5EAA and 2EAA treatments, respectively. Amino acids were infused at the following rates $(\mathrm{g} / \mathrm{d})$ for the 1.5 and 2 EAA treatments, respectively: L-Arg (59 and 78), L-His (48 and 64), L-Ile (86 and 115), L-Val (96 and 128), L-Leu (141 and 188), L-Phe (141 and 188), DL-Met (41 and 55), L-Lys (147 and 196), L-Thr (63 and 85), and L-Trp (21 and 28).

Milk was collected, weighed, and sampled separately from the front and rear mammary glands at each milking during the entire 5 -d infusion period. Milk samples were stored at $4^{\circ} \mathrm{C}$ and analyzed within $3 \mathrm{~d}$. Mammary biopsies were collected at the end of each period (data not shown), necessitating separate milk collection from the front and rear mammary glands.

Blood samples were taken concurrently from the coccygeal vessels and the subcutaneous abdominal vein into sodium heparin and potassium EDTA Vacutainers (Becton Dickinson, Rutherford, NJ) on d 4 of the infusion period at 0800, 1000, 1200, and $1400 \mathrm{~h}$. Samples were collected from the left and right subcutaneous abdominal veins, alternating sides with each time point to avoid oversampling a particular area and to account for differences between sides. Collection tubes were immediately placed in ice and centrifuged at 3,000 $\times g$ for 15 min at room temperature. Plasma was transferred into polypropylene tubes and frozen at $-20^{\circ} \mathrm{C}$ until analysis.

After the morning milking at the end of each $5-\mathrm{d}$ infusion period, muscle tissue was collected by biopsy from the left or right longissimus dorsi muscle in the L1 to L6 vertebral region, alternating sides in successive periods. Cows were sedated with $0.5 \mathrm{~mL}$ of intravenous xylazine, and $10 \mathrm{~mL}$ of lidocaine was injected anterior to the biopsy site as an intercostal nerve block. An incision approximately $3 \mathrm{~cm}$ in length was made through the skin in the intercostal space perpendicular to the vertebrae, and approximately $500 \mathrm{mg}$ of muscle tissue was removed with a 6-mm biopsy punch (Integra Miltex, Burlington, ON, Canada). Muscle samples were immediately rinsed in saline, snap frozen in liquid $\mathrm{N}_{2}$, and stored at $-80^{\circ} \mathrm{C}$ until analysis.

\section{Milk and Plasma Analysis}

Milk samples were analyzed for fat, protein, lactose (Laboratory Services Division, University of Guelph, Guelph, ON), and milk urea nitrogen (CanWest DHI Ontario, DHI Milk Analysis Centre, Guelph, ON) by infrared spectroscopy. Arterial or venous plasma samples were pooled over time for each cow by period and analyzed for glucose, BHB, nonesterified fatty acids (NEFA), triacylglycerol (TAG), acetate, and urea as described by Weekes et al. (2006), and free glycerol according to Bucolo and David (1973). Insulin was analyzed by immunoassay (Crystal Chem Inc., Downers Grove, IL). Long-chain fatty acid concentrations were calculated on a molar basis as $3 \times$ TAG + NEFA. Amino acid concentrations in plasma samples collected at 1000, 1200, and $1400 \mathrm{~h}$ were analyzed using ultra-performance liquid chromatography in conjunction with Empower Chromatography Data Software (Waters Corporation, Milford, MA) according to the protocol described by Boogers et al. (2008). A $250 \mu M$ 3-methyl-L-His standard solution (Sigma-Aldrich, St. Louis, MO) was run to quantify plasma 3-methylhistidine (3M-His) concentrations.

\section{Western Blot Analysis and Quantitative Real-Time PCR}

Approximately $50 \mathrm{mg}$ of muscle tissue was homogenized for $10 \mathrm{~s}$ in $0.5 \mathrm{~mL}$ of lysis buffer (1\% Triton $\mathrm{X}-100,0.1 \%$ SDS, $50 \mathrm{~m} M$ Tris- $\mathrm{HCl} \mathrm{pH} 8.0,150 \mathrm{~m} M$ $\mathrm{NaCl}$, and $0.5 \%$ sodium deoxycholate) containing protease and phosphatase inhibitors (Thermo Scientific, Nepean, ON, Canada). Homogenates were inverted for $1 \mathrm{~h}$ at $4^{\circ} \mathrm{C}$, and then centrifuged at $13,000 \times g$ for 20 min at $4^{\circ} \mathrm{C}$. Muscle supernatants were diluted with lysis buffer to $3 \mu \mathrm{g} / \mu \mathrm{L}$, and further diluted to $1.5 \mu \mathrm{g} /$ $\mu \mathrm{L}$ with sample buffer (4\% SDS, $20 \%$ glycerol, $10 \%$ $\beta$-mercaptoethanol, $0.125 M$ Tris HCL, and $0.004 \%$ bromophenol blue), before boiling at $90^{\circ} \mathrm{C}$ for $5 \mathrm{~min}$. Ten microliters of boiled muscle sample containing 15 $\mu \mathrm{g}$ of total protein and BLUeye Prestained Protein Ladder (FroggaBio, Toronto, ON, Canada) was separated by $8 \%$ SDS-PAGE at $120 \mathrm{~V}$ for approximately $90 \mathrm{~min}$. Proteins were electrotransferred (Mini Trans-Blot, BioRad Laboratories Inc., Mississauga, ON, Canada) onto polyvinylidene difluoride membranes (Millipore, Mississauga, ON, Canada) at $100 \mathrm{~V}$ for $60 \mathrm{~min}$. Membranes were incubated at room temperature for $1 \mathrm{~h}$ in Trisbuffered saline-Tween (TBST) buffer containing 5\% nonfat dry milk before incubation at room temperature with rabbit monoclonal antibodies to branched-chain aminotransferase 1 (BCAT1; \#12822, Cell Signaling, Danvers, MA) and branched-chain o-keto acid dehydrogenase kinase (BCKDH-K; ab128935, Abcam, Cambridge, MA). All primary antibodies were diluted using $1 \%$ milk TBST buffer. Membranes were rinsed with TBST buffer and incubated at room temperature for $1 \mathrm{~h}$ with horseradish peroxidase-linked anti-rabbit IgG (NA934V, GE Healthcare Life Sciences, Mississauga, ON, Canada) diluted in TBST buffer. Following six 5 -min washes of the membranes in TBST buffer, proteins were developed using chemiluminescence (Clarity Western ECL Substrate, Bio-Rad). All membranes first 
probed with proteins of interest underwent three 5-min washes in TBST buffer and appropriate portions were re-probed with antibody against glyceraldehyde 3-phosphate dehydrogenase (GAPDH; ab8245, Abcam) as a loading control. Blot densities in scanned images were determined by ImageLab software (BioRad) and normalized to the corresponding GAPDH blot density.

Total RNA was isolated from approximately $100 \mathrm{mg}$ of muscle tissue using $1 \mathrm{~mL}$ of TRizol Reagent (Invitrogen, Life Technologies, Burlington, ON, Canada), according to the manufacturer's instructions. Quality of RNA was determined with a $1 \%$ agarose TBE gel (40 $\mathrm{m} M$ Tris base, $40 \mathrm{~m} M$ boric acid, $0.2 \% 0.5 M$ EDTA pH 8.0) by staining with ethidium bromide. Primers were designed to yield PCR amplification products of 100 to $200 \mathrm{bp}$ for BCAT1 and the branched-chain $\alpha$-keto acid dehydrogenase complex (BCKDH; Table 2). The cDNA was synthesized from $500 \mathrm{ng}$ of extracted total RNA with random hexamers using a High Capacity cDNA Reverse Transcription Kit (Applied BioSystems, Waltham, MA), following the manufacturer's instructions. The qPCR was carried out using PerfeCta SYBR Green FastMix (Quanta BioScience, Gaithersburg, MD) with an Applied Biosystems 7300 Real Time PCR instrument. Fold changes in gene expression relative to SAL were calculated by the $2^{\Delta \Delta \mathrm{Ct}}$ method (Livak and Schmittgen, 2001) after normalizing to GAPDH.

\section{Calculations and Statistical Analysis}

Milk crude protein yield was adjusted to true protein yield using a factor of 5.5\% (DePeters and Ferguson, 1992). All following calculations were based on this estimate of true protein yield. Mammary plasma flow (MPF) across the whole udder was estimated according to the Fick principle using Phe and Tyr as internal markers (Cant et al., 1993), where MPF $(\mathrm{L} / \mathrm{h})=$ milk Phe + Tyr output $(\mu \mathrm{mol} / \mathrm{h}) /$ arteriovenous Phe + Tyr difference $(\mu \mathrm{mol} / \mathrm{L})$, with an allowance for $3.5 \%$ contribution from blood-derived proteins. Milk output of Phe + Tyr was estimated from the d- 4 afternoon milk protein yield corresponding to the blood samples taken that day using Phe and Tyr contents reported by Mepham (1987). Mammary clearances $(k)$ of AA and me- tabolites were calculated from the model of Hanigan et al. (1998b), where $k(\mathrm{~L} / \mathrm{h})=$ (arteriovenous difference $\times \mathrm{MPF}) /$ venous concentration. Uptakes $(\mathrm{mmol} / \mathrm{h})$ of AA and metabolites across the mammary glands were calculated as the product of their plasma arteriovenous differences and MPF. Positive arteriovenous differences and uptakes indicate AA removal from plasma, whereas negative values indicate net AA release from the mammary glands. Energy balance was calculated as $\mathrm{NE}_{\text {intake }}$ - $\mathrm{NE}_{\mathrm{L}}-\mathrm{NE}_{\mathrm{M}}$, where $\mathrm{NE}_{\text {intake }}$ was calculated from observed DMI and its estimated net energy content plus the net energy content of EAA and glucose infusions, which were $8.5 \mathrm{MJ} / \mathrm{kg}$ (calculated based on $64 \%$ of the heats of combustion of individual EAA in the infusate) and $11.5 \mathrm{MJ} / \mathrm{kg}$ (Hurtaud et al., 1998), respectively. The $\mathrm{NE}_{\mathrm{L}}$ was obtained from the regression equation of Tyrrell and Reid (1965) against observed milk fat, protein, and lactose yields, and $\mathrm{NE}_{\mathrm{M}}=0.08 \mathrm{BW}^{0.75}(\mathrm{NRC}$, 2001). Metabolizable protein balance was calculated as $\mathrm{MP}_{\text {intake }}-\mathrm{MP}_{\mathrm{L}}-\mathrm{MP}_{\mathrm{M}}$, where $\mathrm{MP}_{\text {intake }}$ was calculated from the observed DMI and its estimated MP content (NRC, 2001) plus the EAA infusates, and $\mathrm{MP}_{\mathrm{L}}$ and $\mathrm{MP}_{\mathrm{M}}$ were calculated using NRC (2001) requirement equations.

Milk yield, milk composition, and DMI were averaged over the final $2 \mathrm{~d}$ of each period. Plasma AA concentrations were averaged over the 3 sampling times on d 4 of each period. Variances in lactation performance, plasma concentrations, arteriovenous differences, mammary clearances and uptakes, protein abundance, and gene expression were analyzed using the MIXED procedure of SAS (SAS Institute Inc., Cary, NC) according to the following model:

$$
\mathrm{Y}_{\mathrm{ijk}}=\mu+\operatorname{cow}_{\mathrm{i}}+\operatorname{per}_{\mathrm{j}}+\operatorname{trt}_{\mathrm{k}}+\varepsilon_{\mathrm{ijk}}
$$

where $\mu=$ mean, cow $_{i}=$ ith random cow effect $(i=1$ to 5$), \operatorname{per}_{\mathrm{j}}=\mathrm{jth}$ fixed period effect $(\mathrm{j}=1$ to 5$), \operatorname{trt}_{\mathrm{k}}$ $=\mathrm{kth}$ fixed treatment effect $(\mathrm{k}=1$ to 5$)$, and $\varepsilon_{\mathrm{ijk}}=$ random variation. Effects of EAA were estimated as linear contrasts of $0,1.5 \mathrm{EAA}$, and 2EAA without glucose, using coefficients calculated with PROC IML of SAS. Effects of 1.5EAA+GLC and 2EAA+GLC (GLC) were estimated from orthogonal contrasts between

Table 2. Primer sequences for quantitative real-time PCR in bovine mammary and muscle tissue

\begin{tabular}{|c|c|c|c|c|}
\hline Database & Gene & Protein & Primer sequence & Product size \\
\hline NM_174506 & $B C K D H A$ & $\mathrm{BCKDH}$ & $\begin{array}{l}\text { 5'-TTTGGAGACCAAGTCGAGGC } \\
\text { 3'-GAAATCTAGCCAGCCCACGA }\end{array}$ & 81 \\
\hline NM_001034034 & $G A P D H$ & GAPDH & $\begin{array}{l}\text { 5'-GGGTCATCATCTCTGCACCT } \\
\text { 3'-GGTCATAAGTCCCTCCACGA }\end{array}$ & 176 \\
\hline
\end{tabular}


1.5EAA and 2EAA (EAA) treatments with and without glucose. Treatment means were also separated by Tukey's means separation procedure. Differences were considered significant at $P \leq 0.05$ and tendencies at $0.05<P \leq 0.15$. No significant differences were found between 1.5EAA and 2EAA by Tukey's test. Interactions between EAA and GLC were not estimable due to the incomplete factorial design of the experiment. Milk production and composition data from the front and rear mammary glands were subjected to statistical analysis separately, but treatment effects were not different. The results presented herein are from the front and rear mammary glands combined.

\section{RESULTS}

\section{Dry Matter Intake and Milk Yield}

Dry matter intake was $17 \mathrm{~kg} / \mathrm{d}$ during EAA infusions and decreased $0.6 \mathrm{~kg} / \mathrm{d}$ with GLC $(P=0.04$; Table $3)$. Milk yield increased $4.1 \mathrm{~kg} / \mathrm{d}$ in response to EAA compared with SAL $(P<0.001)$ and tended to further increase $1.5 \mathrm{~kg} / \mathrm{d}$ with GLC $(P=0.057)$. The EAA tended to increase milk fat yield $(P=0.123)$, whereas GLC infusion decreased milk fat yield by $99 \mathrm{~g} / \mathrm{d}(P=$ $0.038)$ and concentration by 0.42 units $(P=0.007)$. Compared with SAL, EAA stimulated an increase in milk CP yield by $256 \mathrm{~g} / \mathrm{d}(P<0.001)$ and concentration by 0.40 units $(P<0.001)$. Infusion of GLC had no effect on protein yield $(P=0.318)$ and tended to decrease protein content $(P=0.097)$. Lactose yield was increased with EAA infusion by $179 \mathrm{~g} / \mathrm{d}(P=0.002)$ and by $262 \mathrm{~g} / \mathrm{d}$ with GLC $(P=0.046)$. Milk urea nitrogen content increased $70 \%(P<0.001)$ with EAA compared with SAL and subsequently decreased $17 \%$ in response to $\operatorname{GLC}(P=0.021)$.

\section{Arterial AA Concentrations, Mammary Plasma Flow, and $A A$ Kinetics}

Infusion of EAA increased the arterial concentration of total EAA to 3.5 times that of the SAL treatment $(P<0.001$; Table 4). Nonessential AA concentrations decreased 20\% $(P<0.001)$ except Asp $(P=0.746)$ and Gln, which only tended to decrease $(P=0.114)$, and Glu and Tyr, which increased $(P<0.015)$. The addition of glucose to EAA infusates decreased arterial BCAA concentrations by $29 \%(P<0.001)$, tended to decrease Arg and Lys by $18 \%$ each $(P<0.150)$, and increased Thr by $38 \%(P<0.001)$. Of the NEAA, Ser increased with GLC $(P<0.001)$, Pro decreased $(P=0.028)$, and Gln and Glu tended to decrease by $14(P=0.098)$ and $7 \%(P=0.076)$, respectively. Plasma concentration of $3 \mathrm{M}-\mathrm{His}$, a marker of muscle protein turnover, tended to increase $50 \%$ in response to EAA compared with SAL $(P=0.054$; Table 4). Addition of glucose had no effect on circulating $3 \mathrm{M}-\mathrm{His}$ concentration.

Infusion of EAA increased the arteriovenous (AV) difference of total EAA $(P=0.001$; Table 5$)$ by $83 \%$ compared with SAL. Individually, AV differences for all EAA increased significantly $(P<0.035)$ except Arg and Trp, which only tended to increase $(P \leq 0.61)$. Arteriovenous difference for total NEAA was unaffected by EAA infusion $(P=0.274)$, but AV difference for Asp $(P=0.003)$, Glu $(P=0.017)$, and Ser $(P=$ 0.088 ) decreased. Addition of glucose to EAA infusates tended to decrease total EAA AV difference by $17 \%(P$ $=0.093)$, with individual decreases seen for His, Lys,

Table 3. Performance of lactating dairy cows $(n=5)$ receiving abomasal infusions of EAA and glucose (GLC) for $5 d^{1}$

\begin{tabular}{|c|c|c|c|c|c|c|c|c|}
\hline Item & \multicolumn{5}{|c|}{ Treatment $^{2}$} & SEM & \multicolumn{2}{|c|}{$P$-value ${ }^{3}$} \\
\hline Milk $(\mathrm{kg} / \mathrm{d})$ & 30.0 & 33.8 & 34.4 & 35.4 & 35.8 & 1.3 & $<0.001$ & 0.057 \\
\hline Fat $(\mathrm{g} / \mathrm{d})$ & 914 & 1,023 & 995 & 914 & 907 & 120 & 0.123 & 0.038 \\
\hline Protein $(\mathrm{g} / \mathrm{d})$ & 868 & 1,118 & 1,130 & 1,139 & 1,156 & 54 & $<0.001$ & 0.318 \\
\hline Fat & 3.08 & 3.03 & 2.91 & 2.56 & 2.54 & 0.35 & 0.447 & 0.007 \\
\hline Protein & 2.90 & 3.31 & 3.28 & 3.22 & 3.23 & 0.09 & $<0.001$ & 0.097 \\
\hline Lactose & 4.73 & 4.71 & 4.67 & 4.74 & 4.70 & 0.08 & 0.136 & 0.280 \\
\hline MUN (mg/dL) & 4.1 & 6.7 & 7.3 & 5.6 & 6.0 & 1.0 & $<0.001$ & 0.021 \\
\hline $\mathrm{BW}(\mathrm{kg})$ & 581 & 582 & 586 & 585 & 584 & 31 & 0.406 & 0.868 \\
\hline $\mathrm{BCS}$ & 2.45 & 2.45 & 2.48 & 2.53 & 2.48 & 0.09 & 0.594 & 0.207 \\
\hline
\end{tabular}

${ }^{1}$ Data are least squares means from the final $2 \mathrm{~d}$ of each period.

${ }^{2}$ Infusion treatments were $0.9 \%$ saline (SAL), or complete mixtures of EAA with the same profile and amount as found in 1,500 and $2,000 \mathrm{~g}$ of casein according to Metcalf et al. (1996), with or without the inclusion of $1 \mathrm{~kg}$ of glucose (1.5EAA, 2EAA, 1.5+GLC, and 2+GLC, respectively).

${ }^{3} P_{\mathrm{EAA}}=$ linear effect of EAA without GLC; $P_{\mathrm{GLC}}=$ effect of GLC. 
Table 4. Arterial plasma concentrations of AA and 3-methylhistidine (3M-His; $\mu M)$ in lactating dairy cows $(\mathrm{n}=5)$ receiving abomasal infusions of EAA and glucose (GLC) for $5 \mathrm{~d}^{1}$

\begin{tabular}{|c|c|c|c|c|c|c|c|c|}
\hline \multirow[b]{2}{*}{ Item } & \multicolumn{5}{|c|}{ Treatment $^{2}$} & \multirow[b]{2}{*}{ SEM } & \multicolumn{2}{|c|}{$P$-value ${ }^{3}$} \\
\hline & $\mathrm{SAL}$ & $1.5 \mathrm{EAA}$ & $2 \mathrm{EAA}$ & $1.5+\mathrm{GLC}$ & $2+\mathrm{GLC}$ & & EAA & GLC \\
\hline Ile & 105 & 286 & 348 & 181 & 252 & 22 & $<0.001$ & $<0.001$ \\
\hline Leu & 107 & 391 & 499 & 240 & 365 & 33 & $<0.001$ & $<0.001$ \\
\hline Lys & 60 & 185 & 243 & 144 & 208 & 27 & $<0.001$ & 0.142 \\
\hline Thr & 84 & 213 & 241 & 294 & 334 & 22 & $<0.001$ & $<0.001$ \\
\hline Trp & 32 & 53 & 58 & 50 & 60 & 3 & $<0.001$ & 0.872 \\
\hline Val & 183 & 643 & 833 & 429 & 656 & 42 & $<0.001$ & $<0.001$ \\
\hline Ala & 234 & 164 & 133 & 169 & 154 & 12 & $<0.001$ & 0.122 \\
\hline Asn & 38 & 32 & 27 & 27 & 27 & 2 & 0.001 & 0.233 \\
\hline Asp & 9 & 9 & 9 & 9 & 9 & 0.4 & 0.746 & 0.617 \\
\hline Gln & 185 & 146 & 165 & 129 & 139 & 12 & 0.114 & 0.098 \\
\hline $\mathrm{BCAA}^{4}$ & 394 & 1,319 & 1,681 & 849 & 1,274 & 94 & $<0.001$ & $<0.001$ \\
\hline $\mathrm{EAA}^{5}$ & 708 & 2250 & 2,803 & 1779 & 2,471 & 167 & $<0.001$ & 0.033 \\
\hline Non-BCAA ${ }^{6}$ & 315 & 931 & 1,122 & 929 & 1,197 & 101 & $<0.001$ & 0.681 \\
\hline $\mathrm{NEAA}^{7}$ & 1,234 & 1,042 & 940 & 1,055 & 982 & 37 & $<0.001$ & 0.313 \\
\hline $\mathrm{TAA}^{8}$ & 1,942 & 3,292 & 3,743 & 2,833 & 3,453 & 170 & $<0.001$ & 0.040 \\
\hline 3M-His & 17 & 27 & 24 & 23 & 23 & 4 & 0.054 & 0.406 \\
\hline
\end{tabular}

${ }^{1}$ Data are least squares means from d 4 of each period.

${ }^{2}$ Infusion treatments were $0.9 \%$ saline (SAL), or complete mixtures of EAA with the same profile and amount as found in 1,500 and 2,000 g of casein according to Metcalf et al. (1996), with or without the inclusion of $1 \mathrm{~kg}$ of glucose (1.5EAA, 2EAA, 1.5+GLC, and 2+GLC, respectively).

${ }^{3} P_{\mathrm{EAA}}=$ linear effect of EAA without GLC; $P_{\mathrm{GLC}}=$ effect of GLC.

${ }^{4} \mathrm{BCAA}=$ branched-chain AA (Ile, Leu, and Val).

${ }^{5} \mathrm{EAA}=\mathrm{Arg}$, His, Ile, Leu, Lys, Met, Phe, Thr, Trp, and Val.

${ }^{6} \mathrm{Non}-\mathrm{BCAA}=\mathrm{EAA}-\mathrm{BCAA}$.

${ }^{7}$ NEAA = Ala, Asn, Asp, Glu, Gly, Gln, Pro, Ser, and Tyr.

${ }^{8} \mathrm{TAA}=\mathrm{EAA}+$ NEAA.

Met, and Trp $(P=0.028-0.135)$. Of the BCAA, AV difference for Val tended to decrease with GLC infusion $(P=0.096)$, whereas Ile and Leu were unaffected $(P>$ 0.2 ). Infusion of GLC had no effect on AV difference of NEAA, except Ala, which tended to decrease $35 \%$ ( $P$ $=0.113$ ).

Mammary plasma flow was unaffected by treatment $(P>0.241$; Table 6$)$. Mammary clearances of individual EAA decreased 43 (Arg) to $89 \%$ (His) with EAA infusion compared with SAL $(P<0.05$; Table $6)$, except Trp clearance, which was unchanged $(P=$ $0.617)$. The clearance of total NEAA was unaffected by EAA infusion $(P=0.979)$, but Asp, Glu, and Tyr clearances were decreased individually $(P \leq 0.026)$. The addition of glucose to EAA infusates decreased clearance of Thr $(P=0.021)$ and $\operatorname{Trp}(P=0.107)$ by 41 and $28 \%$, respectively, and the clearance of total BCAA was increased $48 \%(P=0.009)$ by GLC infusion. Although Val clearance was not affected, Ile and Leu clearances increased $79(P=0.005)$ and $85 \%(P=$
$0.004)$, respectively. Of the NEAA, Ala $(P=0.049)$ and Tyr $(P=0.074)$ clearances decreased with GLC, and Asp clearance increased $(P=0.102)$.

Mammary uptakes of all individual EAA increased by 22 (Arg) to $91 \%$ (Val) with infusion of EAA compared with SAL $(P<0.001$; Table 7$)$. The EAA infusion decreased uptakes of Asp $(P<0.001)$, Glu $(P$ $=0.002)$, and Ser $(P=0.035)$ by 65,34 , and $30 \%$, respectively, but did not affect uptakes of other NEAA. Infusion of GLC had no effect on the uptake of total EAA, BCAA, non-BCAA, or NEAA but tended to decrease mammary uptake of His, Trp, and Val by 20, 23 , and $16 \%$, respectively $(P<0.1)$ and increase the uptake of Ile, Phe, and Asp by 8, 8, and 64\% ( $P \leq$ $0.141)$, respectively.

\section{Insulin and Metabolites}

Insulin concentration was unaffected by EAA $(P=$ $0.494)$ but increased 53\% ( $P=0.019)$ with GLC infu- 
sion (Table 8). Arterial plasma glucose concentration was not affected by EAA $(P=0.681)$ and increased $16 \%(P<0.001)$ with GLC. Plasma BHB and acetate decreased with GLC infusion by $63(P=0.008)$ and $34 \%(P=0.012)$, respectively. Arterial NEFA concentration increased $32 \%(P=0.004)$ with EAA infusion, and decreased to SAL levels $(P<0.001)$ with GLC. Total long-chain fatty acid concentration tended to decrease when glucose was added to EAA infusions $(P$ $=0.123)$. Plasma urea concentration during EAA infusion increased 2-fold compared with SAL $(P<0.001)$, whereas GLC had no effect.

Infusion of EAA had no effect on AV difference of any plasma metabolites (Table 9), but GLC infusion tended to decrease AV difference of acetate $(P=0.122)$ and NEFA $(P=0.112)$. Mammary gland clearance of NEFA tended to decrease $50 \%$ with EAA infusion $(P$ $=0.131$; Table 9). Compared with EAA, GLC tended to increase clearances of BHB 2.1-fold $(P=0.148)$ and TAG by $97 \%(P=0.144)$. Mammary gland uptake of plasma glucose tended to be $20 \%$ higher during GLC infusion $(P=0.127)$, but uptakes of all metabolites (Table 9) were not otherwise affected by EAA or GLC treatments.

\section{Protein Abundance and Gene Expression}

Abundance of BCKDH-K in skeletal muscle decreased with EAA $(P=0.022$; Figure 1$)$, and the abundance of BCAT1 was unaffected by EAA or GLC treatments. The expression of BCKDH mRNA was unaffected by treatment, but BCAT1 expression decreased when GLC was infused $(P=0.040$; Figure 2$)$.

\section{DISCUSSION}

\section{AA Supply and Partitioning}

The objective of this study was to determine whether glucose would stimulate milk protein yield when EAA

Table 5. Mammary gland arteriovenous differences $(\mu M)$ of AA in lactating dairy cows $(\mathrm{n}=5)$ receiving abomasal infusions of EAA and glucose (GLC) for $5 \mathrm{~d}^{1}$

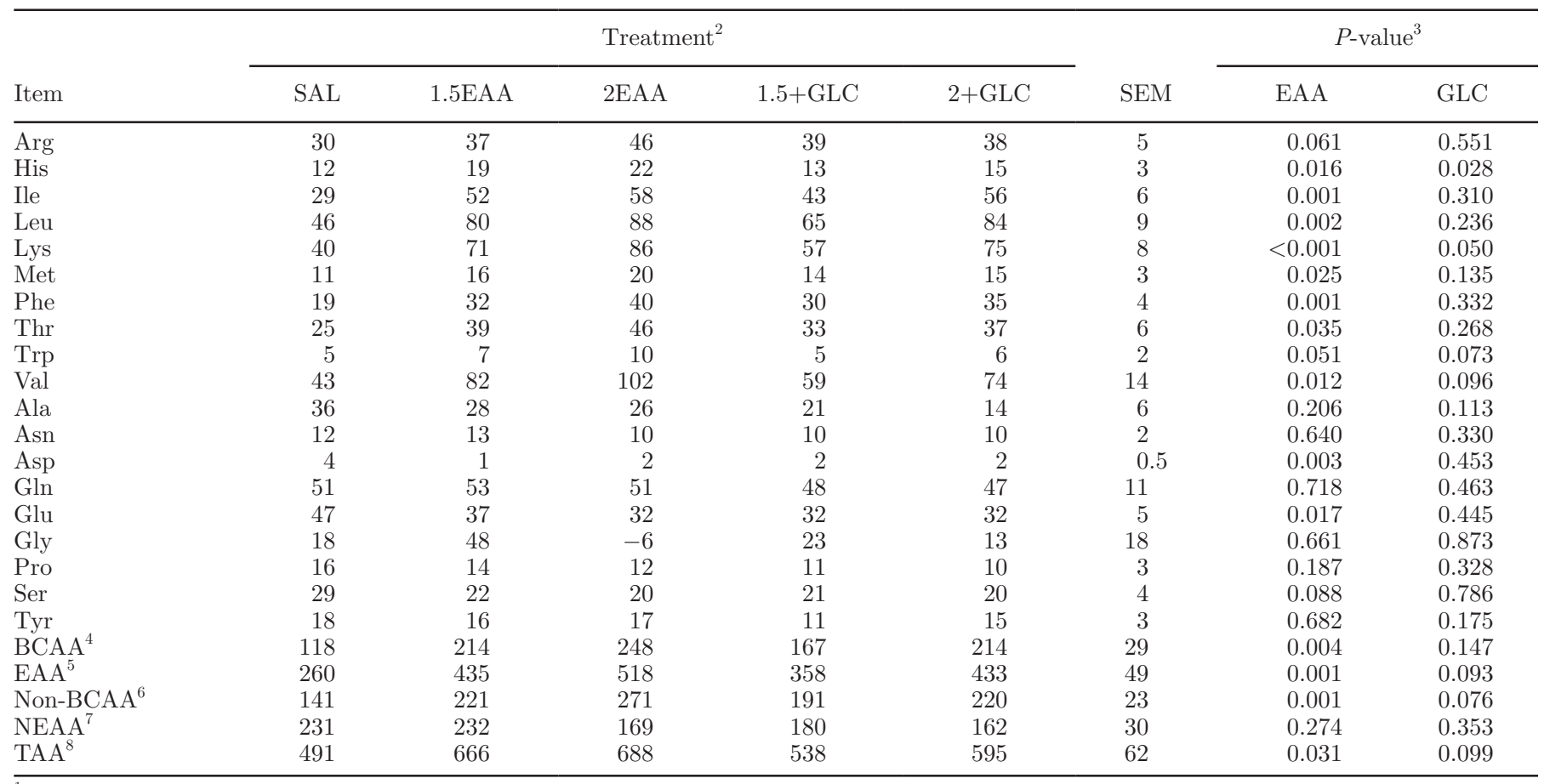

${ }^{1}$ Data are least squares means from $\mathrm{d} 4$ of each period.

${ }^{2}$ Infusion treatments were $0.9 \%$ saline (SAL), or complete mixtures of EAA with the same profile and amount as found in 1,500 and $2,000 \mathrm{~g}$ of casein according to Metcalf et al. (1996), with or without the inclusion of $1 \mathrm{~kg}$ of glucose (1.5EAA, 2EAA, 1.5+GLC, and 2+GLC, respectively).

${ }^{3} P_{\mathrm{EAA}}=$ linear effect of EAA without GLC; $P_{\mathrm{GLC}}=$ effect of GLC

${ }^{4} \mathrm{BCAA}=$ branched-chain AA (Ile, Leu, and Val).

${ }^{5} \mathrm{EAA}=$ Arg, His, Ile, Leu, Lys, Met, Phe, Thr, Trp, and Val.

${ }^{6}$ Non-BCAA $=$ EAA - BCAA.

${ }^{7}$ NEAA $=$ Ala, Asn, Asp, Glu, Gly, Gln, Pro, Ser, and Tyr.

${ }^{8} \mathrm{TAA}=\mathrm{EAA}+\mathrm{NEAA}$. 
were not limiting for mammary protein synthesis. Metabolizable protein supply from the diet was estimated using NRC (2001) to be $1,322 \mathrm{~g} / \mathrm{d}$ on average and 2,170 and $2,432 \mathrm{~g} / \mathrm{d}$ including the EAA infusates (844 and $1,126 \mathrm{~g} / \mathrm{d}$, respectively; Table 10). To the authors' knowledge, $1,126 \mathrm{~g} / \mathrm{d}$ is the highest reported level of a complete EAA mixture to be infused into cows. Metcalf et al. (1996) infused $208 \mathrm{~g} / \mathrm{d}$ of EAA into a jugular vein of cows fed a $14.5 \% \mathrm{CP}$ diet and stimulated milk true protein yield by $143 \mathrm{~g} / \mathrm{d}$. When Doelman et al. $(2015 \mathrm{a}, \mathrm{b})$ infused $563 \mathrm{~g} / \mathrm{d}$ of exclusively EAA on an $11.2 \%$ CP diet, milk true protein yield increased by 165 and $145 \mathrm{~g} / \mathrm{d}$, respectively. Our daily infusion of $1126 \mathrm{~g}$ increased plasma EAA concentration 3.5-fold and stimulated milk true protein yield by $248 \mathrm{~g} / \mathrm{d}$.

Based on NRC (2001) calculations using basal diet intakes, the MP-allowable milk was $47 \%$ of the NEallowable milk (Table 10) and the average DMI of the basal diet across all treatments supported a milk true protein yield of $324 \mathrm{~g} / \mathrm{d}$ (Table 11). During SAL infusion, the actual milk true protein yield of $820 \mathrm{~g} / \mathrm{d}$ in comparison with the $332 \mathrm{~g} / \mathrm{d}$ diet allowed milk protein yield suggests that this difference was supported by an additional $488 \mathrm{~g} / \mathrm{d}$ of MP from spared catabolism and labile MP sources within the body, including muscle, splanchnic, and circulating protein and peptide pools (Table 11).

Milk true protein yield increased to $1,068 \mathrm{~g} / \mathrm{d}$ in response to $1,126 \mathrm{~g} / \mathrm{d}$ of EAA from $2 \mathrm{EAA}$ infusion, with the basal diet supporting $332 \mathrm{~g} / \mathrm{d}$ of this protein yield (NRC, 2001; Table 11). Of the $736 \mathrm{~g} / \mathrm{d}$ difference between diet-allowed protein yield and observed protein yield, $383 \mathrm{~g} / \mathrm{d}$ were EAA that could have come entirely from the infusate, potentially mitigating the need for MP mobilization from labile pools. In fact, if the $383 \mathrm{~g} / \mathrm{d}$ came entirely from the EAA infusate, then $743 \mathrm{~g} / \mathrm{d}$ of infused EAA were available to replenish labile MP stores or be catabolized. Some of this excess

Table 6. Whole-mammary gland plasma flow $(\mathrm{L} / \mathrm{h})$ and clearances $(k, \mathrm{~L} / \mathrm{h})$ of AA in lactating dairy cows $(\mathrm{n}=5)$ receiving abomasal infusions of EAA and glucose (GLC) for $5 \mathrm{~d}^{1}$

\begin{tabular}{|c|c|c|c|c|c|c|c|c|}
\hline Item & \multicolumn{5}{|c|}{ Treatment $^{2}$} & SEM & \multicolumn{2}{|c|}{$P$-value ${ }^{3}$} \\
\hline $\begin{array}{l}\text { Plasma flow } \\
k\end{array}$ & 612 & 569 & 528 & 688 & 585 & 71 & 0.438 & 0.241 \\
\hline Arg & 551 & 352 & 282 & 500 & 273 & 88 & 0.046 & 0.448 \\
\hline His & 1,133 & 140 & 117 & 100 & 80 & 110 & $<0.001$ & 0.723 \\
\hline Ile & 212 & 131 & 97 & 248 & 160 & 29 & 0.008 & 0.005 \\
\hline Phe & 511 & 183 & 150 & 236 & 120 & 33 & $<0.001$ & 0.708 \\
\hline Thr & 243 & 141 & 114 & 76 & 75 & 20 & $<0.001$ & 0.021 \\
\hline Trp & 99 & 93 & 89 & 72 & 59 & 15 & 0.617 & 0.107 \\
\hline Val & 173 & 87 & 64 & 105 & 71 & 13 & $<0.001$ & 0.342 \\
\hline Ala & 103 & 147 & 145 & 90 & 73 & 35 & 0.272 & 0.049 \\
\hline Asn & 244 & 405 & 287 & 415 & 344 & 47 & 0.215 & 0.493 \\
\hline Ser & 283 & 277 & 231 & 240 & 186 & 59 & 0.586 & 0.473 \\
\hline Tyr & 424 & 352 & 214 & 172 & 187 & 81 & 0.026 & 0.074 \\
\hline $\mathrm{BCAA}^{4}$ & 241 & 115 & 82 & 178 & 113 & 19 & $<0.001$ & 0.009 \\
\hline $\mathrm{EAA}^{5}$ & 327 & 147 & 110 & 180 & 122 & 18 & $<0.001$ & 0.192 \\
\hline Non-BCAA ${ }^{6}$ & 465 & 215 & 169 & 183 & 134 & 27 & $<0.001$ & 0.241 \\
\hline $\mathrm{NEAA}^{7}$ & 129 & 168 & 115 & 137 & 117 & 23 & 0.979 & 0.523 \\
\hline $\mathrm{TAA}^{8}$ & 190 & 155 & 112 & 160 & 120 & 17 & 0.011 & 0.698 \\
\hline
\end{tabular}

${ }^{1}$ Data are least squares means from d 4 of each period.

${ }^{2}$ Infusion treatments were $0.9 \%$ saline (SAL), or complete mixtures of EAA with the same profile and amount as found in 1,500 and 2,000 g of casein according to Metcalf et al. (1996), with or without the inclusion of $1 \mathrm{~kg}$ of glucose (1.5EAA, 2EAA, 1.5+GLC, and 2+GLC, respectively).

${ }^{3} P_{\mathrm{EAA}}=$ linear effect of EAA without GLC; $P_{\mathrm{GLC}}=$ effect of GLC.

${ }^{4} \mathrm{BCAA}=$ branched-chain AA (Ile, Leu, and Val).

${ }^{5} \mathrm{EAA}=$ Arg, His, Ile, Leu, Lys, Met, Phe, Thr, Trp, and Val.

${ }^{6} \mathrm{Non}-\mathrm{BCAA}=\mathrm{EAA}-\mathrm{BCAA}$.

${ }^{7} \mathrm{NEAA}=$ Ala, Asn, Asp, Glu, Gly, Gln, Pro, Ser, and Tyr.

${ }^{8} \mathrm{TAA}=\mathrm{EAA}+\mathrm{NEAA}$. 
Table 7. Mammary gland uptakes $(\mathrm{mmol} / \mathrm{h})$ of AA in lactating dairy cows $(\mathrm{n}=5)$ receiving abomasal infusions of EAA and glucose (GLC) for $5 \mathrm{~d}^{1}$

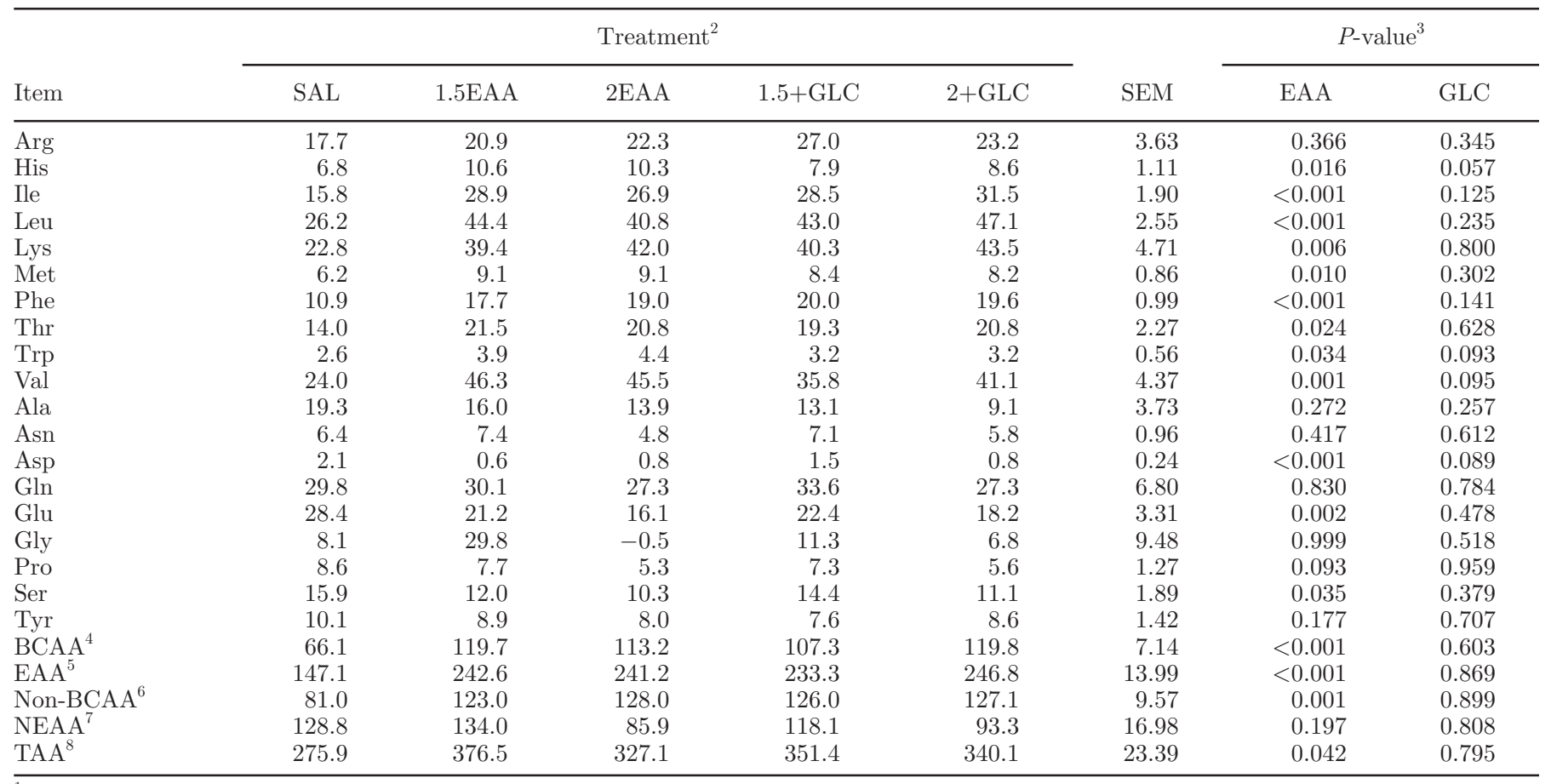

${ }^{1}$ Data are least squares means from $\mathrm{d} 4$ of each period.

${ }^{2}$ Infusion treatments were $0.9 \%$ saline (SAL), or complete mixtures of EAA with the same profile and amount as found in 1,500 and 2,000 g of casein according to Metcalf et al. (1996), with or without the inclusion of $1 \mathrm{~kg}$ of glucose (1.5EAA, 2EAA, 1.5+GLC, and 2+GLC, respectively).

${ }^{3} P_{\mathrm{EAA}}=$ linear effect of EAA without GLC; $P_{\mathrm{GLC}}=$ effect of GLC

${ }^{4} \mathrm{BCAA}=$ branched-chain AA (Ile, Leu, and Val).

${ }^{5} \mathrm{EAA}=$ Arg, His, Ile, Leu, Lys, Met, Phe, Thr, Trp, and Val.

${ }^{6} \mathrm{Non}-\mathrm{BCAA}=\mathrm{EAA}-\mathrm{BCAA}$.

${ }^{7} \mathrm{NEAA}=$ Ala, Asn, Asp, Glu, Gly, Gln, Pro, Ser, and Tyr.

${ }^{8} \mathrm{TAA}=\mathrm{EAA}+\mathrm{NEAA}$.

EAA was used to synthesize NEAA in the mammary gland because NEAA output in milk protein increased on 2EAA compared with SAL, even though mammary
NEAA uptake did not change. Between 2EAA and SAL, mammary uptake of EAA increased $311 \mathrm{~g} / \mathrm{d}$, which is $183 \mathrm{~g} / \mathrm{d}$ more than the $128 \mathrm{~g} / \mathrm{d}$ increase in

Table 8. Arterial plasma concentrations of metabolites and insulin in lactating dairy cows $(\mathrm{n}=5)$ receiving abomasal infusions of EAA and glucose (GLC) for $5 \mathrm{~d}^{1}$

\begin{tabular}{|c|c|c|c|c|c|c|c|c|}
\hline \multirow[b]{2}{*}{ Item } & \multicolumn{5}{|c|}{ Treatment $^{2}$} & \multirow[b]{2}{*}{ SEM } & \multicolumn{2}{|c|}{$P$-value ${ }^{3}$} \\
\hline & SAL & $1.5 \mathrm{EAA}$ & $2 \mathrm{EAA}$ & $1.5+\mathrm{GLC}$ & $2+\mathrm{GLC}$ & & EAA & GLC \\
\hline $\mathrm{BHB}(\mathrm{m} M)$ & 0.57 & 1.00 & 0.73 & 0.33 & 0.31 & 0.23 & 0.301 & 0.008 \\
\hline Acetate $(\mathrm{m} M)$ & 1.78 & 1.80 & 1.48 & 1.05 & 1.12 & 0.22 & 0.387 & 0.012 \\
\hline $\begin{array}{l}\text { Nonesterified fatty } \\
\text { acids }(\mu M)\end{array}$ & 131 & 171 & 176 & 117 & 130 & 12 & 0.004 & $<0.001$ \\
\hline Glycerol $(\mu M)$ & 37 & 22 & 28 & 23 & 19 & 6 & 0.210 & 0.508 \\
\hline Urea $(\mathrm{m} M)$ & 0.62 & 1.11 & 1.48 & 1.06 & 1.28 & 0.15 & $<0.001$ & 0.363 \\
\hline Insulin $(\mu \mathrm{g} / \mathrm{L})$ & 0.74 & 0.90 & 0.89 & 1.39 & 1.35 & 0.22 & 0.494 & 0.019 \\
\hline
\end{tabular}

${ }^{1}$ Data are least squares means from d 4 of each period. TAG = triacylglycerol; LCFA = long-chain fatty acid.

${ }^{2}$ Infusion treatments were $0.9 \%$ saline (SAL), or complete mixtures of EAA with the same profile and amount as found in 1,500 and 2,000 g of casein according to Metcalf et al. (1996), with or without the inclusion of $1 \mathrm{~kg}$ of glucose (1.5EAA, 2EAA, 1.5+GLC, and 2+GLC, respectively).

${ }^{3} P_{\mathrm{EAA}}=$ linear effect of EAA without GLC; $P_{\mathrm{GLC}}=$ effect of GLC. 
Table 9. Mammary gland arteriovenous (AV) differences, clearances $(k)$, and uptakes of metabolites in lactating dairy cows $(\mathrm{n}=5)$ receiving abomasal infusions of EAA and glucose (GLC) for $5 \mathrm{~d}^{1}$

\begin{tabular}{|c|c|c|c|c|c|c|c|c|}
\hline \multirow[b]{2}{*}{ Item } & \multicolumn{5}{|c|}{ Treatment $^{2}$} & \multirow[b]{2}{*}{ SEM } & \multicolumn{2}{|c|}{$P$-value ${ }^{3}$} \\
\hline & SAL & $1.5 \mathrm{EAA}$ & $2 \mathrm{EAA}$ & $1.5+\mathrm{GLC}$ & $2+\mathrm{GLC}$ & & EAA & GLC \\
\hline \multicolumn{9}{|l|}{ Glucose } \\
\hline AV difference $(\mathrm{m} M)$ & 0.60 & 0.58 & 0.72 & 0.56 & 0.81 & 0.09 & 0.360 & 0.698 \\
\hline$k(\mathrm{~L} / \mathrm{h})$ & 146 & 174 & 166 & 162 & 182 & 28 & 0.541 & 0.942 \\
\hline Uptake (mmol/h) & 327.3 & 326.3 & 359.5 & 386.1 & 483.0 & 54.5 & 0.738 & 0.107 \\
\hline \multicolumn{9}{|l|}{ BHB } \\
\hline Uptake (mmol/h) & 116.3 & 152.3 & 89.2 & 68.4 & 92.0 & 58.3 & 0.884 & 0.417 \\
\hline \multicolumn{9}{|l|}{ Acetate } \\
\hline AV difference $(\mathrm{m} M)$ & 0.68 & 0.91 & 0.62 & 0.51 & 0.61 & 0.12 & 0.879 & 0.122 \\
\hline$k(\mathrm{~L} / \mathrm{h})$ & 418 & 765 & 441 & 691 & 709 & 136 & 0.430 & 0.402 \\
\hline Uptake $(\mathrm{mmol} / \mathrm{h})$ & 354.5 & 494.2 & 309.2 & 376.4 & 356.7 & 63.8 & 0.927 & 0.592 \\
\hline \multicolumn{9}{|l|}{ Nonesterified fatty acids } \\
\hline AV difference $(\mu M)$ & -43 & -31 & -28 & -55 & -34 & 16 & 0.245 & 0.112 \\
\hline Uptake (mmol/h) & 17.4 & 18.3 & 13.8 & 26.4 & 18.6 & 4.2 & 0.668 & 0.151 \\
\hline \multicolumn{9}{|l|}{ LCFA } \\
\hline AV difference $(\mu M)$ & 47 & 66 & 60 & 54 & 61 & 29 & 0.659 & 0.850 \\
\hline$k(\mathrm{~L} / \mathrm{h})$ & 116 & 169 & 126 & 216 & 208 & 79 & 0.813 & 0.397 \\
\hline Uptake (mmol/h) & 26.0 & 37.4 & 25.2 & 41.2 & 39.2 & 16.1 & 0.888 & 0.569 \\
\hline \multicolumn{9}{|l|}{ Glycerol } \\
\hline AV difference $(\mu M)$ & 14 & 0.6 & 7 & -0.4 & -1 & 5 & 0.169 & 0.373 \\
\hline$k(\mathrm{~L} / \mathrm{h})$ & 268 & 13 & 234 & -22 & -22 & 106 & 0.483 & 0.196 \\
\hline Uptake (mmol/h) & 6.5 & 0.01 & 4.4 & -0.3 & -0.5 & 2.5 & 0.291 & 0.316 \\
\hline
\end{tabular}

${ }^{1}$ Data are least squares means from $\mathrm{d} 4$ of each period.

${ }^{2}$ Infusion treatments were $0.9 \%$ saline (SAL), or complete mixtures of EAA with the same profile and amount as found in 1,500 and $2,000 \mathrm{~g}$ of casein according to Metcalf et al. (1996), with or without the inclusion of $1 \mathrm{~kg}$ of glucose (1.5EAA, 2EAA, 1.5+GLC, and 2+GLC, respectively).

${ }^{3} P_{\mathrm{EAA}}=$ linear effect of EAA without GLC; $P_{\mathrm{GLC}}=$ effect of GLC.

EAA output in milk protein and is sufficient to account for the mammary NEAA deficit. This example of intramammary AA metabolism is in agreement with Doepel and Lapierre (2010), who reported increased mammary EAA uptake in support of both milk protein and NEAA synthesis within the gland.

Decreased mammary clearances for most EAA reflect the surplus of EAA supply for milk protein synthesis, consistent with their elevated plasma concentrations. Mammary plasma flow, which is a determinant of the arterial supply of EAA for mammary uptake, was not affected by EAA infusion. Thus, decreased clearances of EAA between SAL and EAA treatments were related to greater arterial and venous EAA concentrations, despite increased mammary uptake. This agrees with the $61 \%$ surplus of infused EAA not used for milk protein synthesis (Table 11), suggesting that mammary affinity for EAA is reduced when supply is abundant. Mammary clearance of AA and metabolites is part of an adaptive mechanism to match substrate supply with cellular needs of the gland for milk and component synthesis (Rius et al., 2010). The reduced mammary clearance of EAA suggests mammary requirements for maximal protein synthesis were met and supports our hypothesis that surplus infused AA were available for catabolism.

It is interesting that DMI was not affected by EAA infusion, despite the significant increase in circulating EAA in plasma. Typically, intake of surplus AA reduces feed consumption (Gietzen, 1993), but our observations are in line with Weekes et al. (2006), who infused 1,104 $\mathrm{g} / \mathrm{d}$ of a complete AA mixture and reported an increase in plasma AA concentration with no change in DMI.

That EAA infusion stimulated deposition of protein into labile pools and catabolism of AA is supported by the observation that plasma NEAA concentrations declined. Because NEAA were not included in the infusates, this decline indicates stimulation of NEAA utilization. The estimates of mammary NEAA clearance and uptake suggest that this stimulation did not occur at the mammary gland. However, elevated milk and plasma urea concentrations indicate that AA catabolism was indeed stimulated. Typically, when incomplete AA profiles are infused into cows or fed to nonruminants, 
catabolism of all AA, including those not included in the supplement, increases (Cant et al., 2003). A portion of NEAA was likely catabolized in the liver for gluconeogenesis to support milk production (Vanhatalo et al., 2003b). Although we have no direct evidence that AA deposition into labile protein pools also increased, the elevation of plasma 3M-His indicates increased protein degradation in skeletal muscle during EAA infusion. The 3M-His concentration in saline-treated
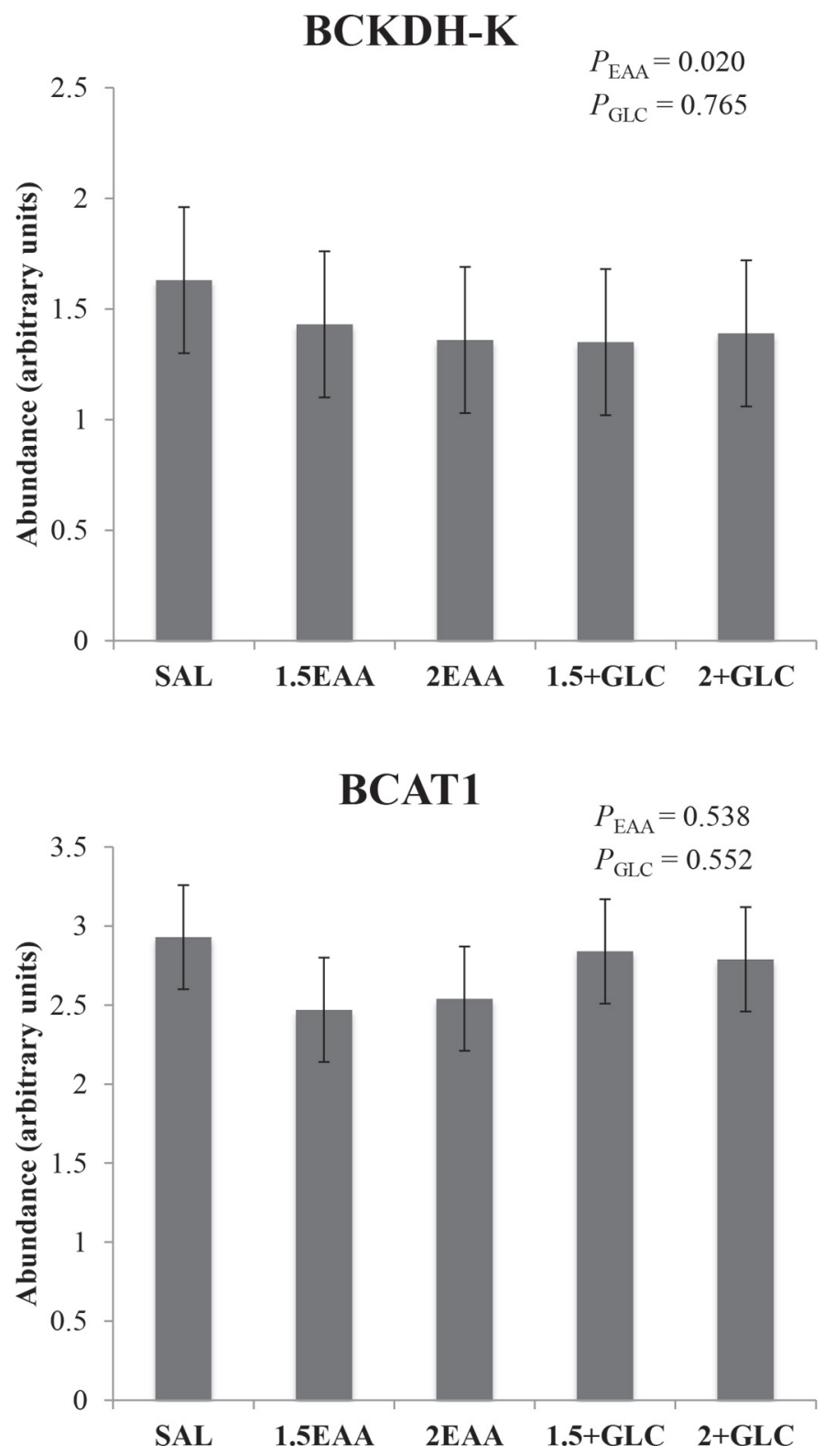

Figure 1. Abundances of branched-chain $\alpha$-keto acid dehydrogenase kinase $(\mathrm{BCKDH}-\mathrm{K})$ and branched-chain aminotransferase 1 (BCAT1) in skeletal muscle of lactating dairy cows $(\mathrm{n}=5)$ after 5 -d abomasal infusion of EAA and GLC. Values are presented as least squares means $\pm \mathrm{SE} ; \mathrm{SAL}=$ saline; $\mathrm{GLC}=$ glucose $; P_{\mathrm{EAA}}=$ linear effect of EAA without GLC; $P_{\mathrm{GLC}}=$ effect of GLC
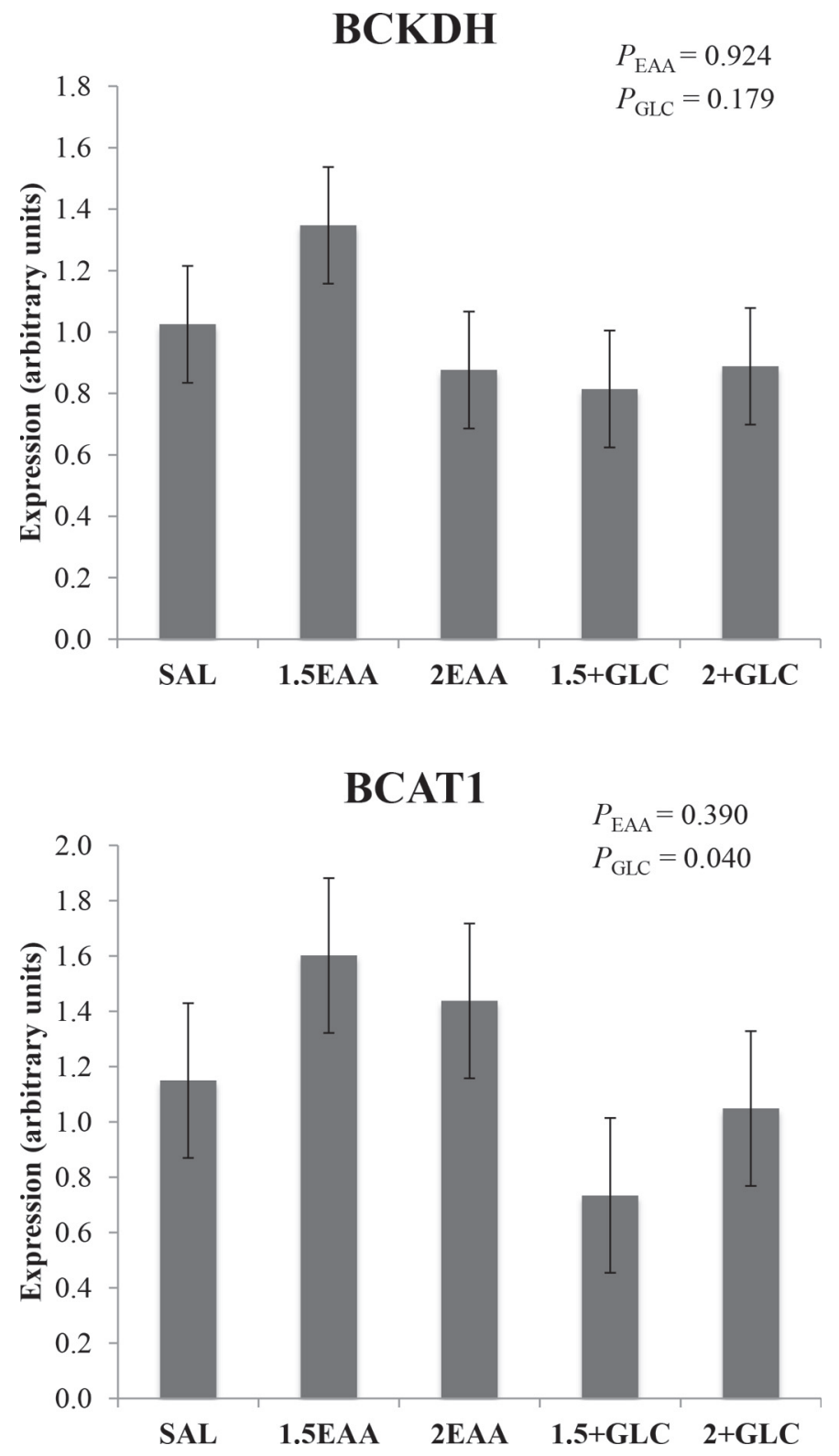

Figure 2. Skeletal muscle gene expression of branched-chain $\alpha$-keto acid dehydrogenase (BCKDH) and branched-chain aminotransferase 1 (BCAT1) in lactating dairy cows $(\mathrm{n}=5)$ after 5 -d abomasal infusion of EAA and GLC. Values are presented as least squares means $\pm \mathrm{SE}$; $\mathrm{SAL}=$ saline $; \mathrm{GLC}=$ glucose $; P_{\mathrm{EAA}}=$ linear effect of $\mathrm{EAA}$ without GLC; $P_{\mathrm{GLC}}=$ effect of GLC

cows was $17 \mu M$, which is similar to $14 \mu M$ reported for cows at 12 wk of lactation (Blum et al., 1985). Concentration of $3 \mathrm{M}$-His increased $40 \%$ to $24 \mu \mathrm{M}$ during EAA infusion. Appuhamy et al. (2011) reported plasma $3 \mathrm{M}-\mathrm{His}$ levels of $10.4 \mu M$ for saline-treated cows that increased by $13 \%$ when jugular infusions of Met and Lys were supplemented with BCAA. Using labeled Leu, Bequette et al. (2002) found that protein synthesis and degradation rates in the hind limb of lactating goats 
Table 10. Estimated MP and $\mathrm{NE}_{\mathrm{L}}$ supplied from the basal diet at observed mean DMI and 5-d abomasal infusions of EAA and glucose (GLC) in lactating dairy cows $(\mathrm{n}=5)^{1}$

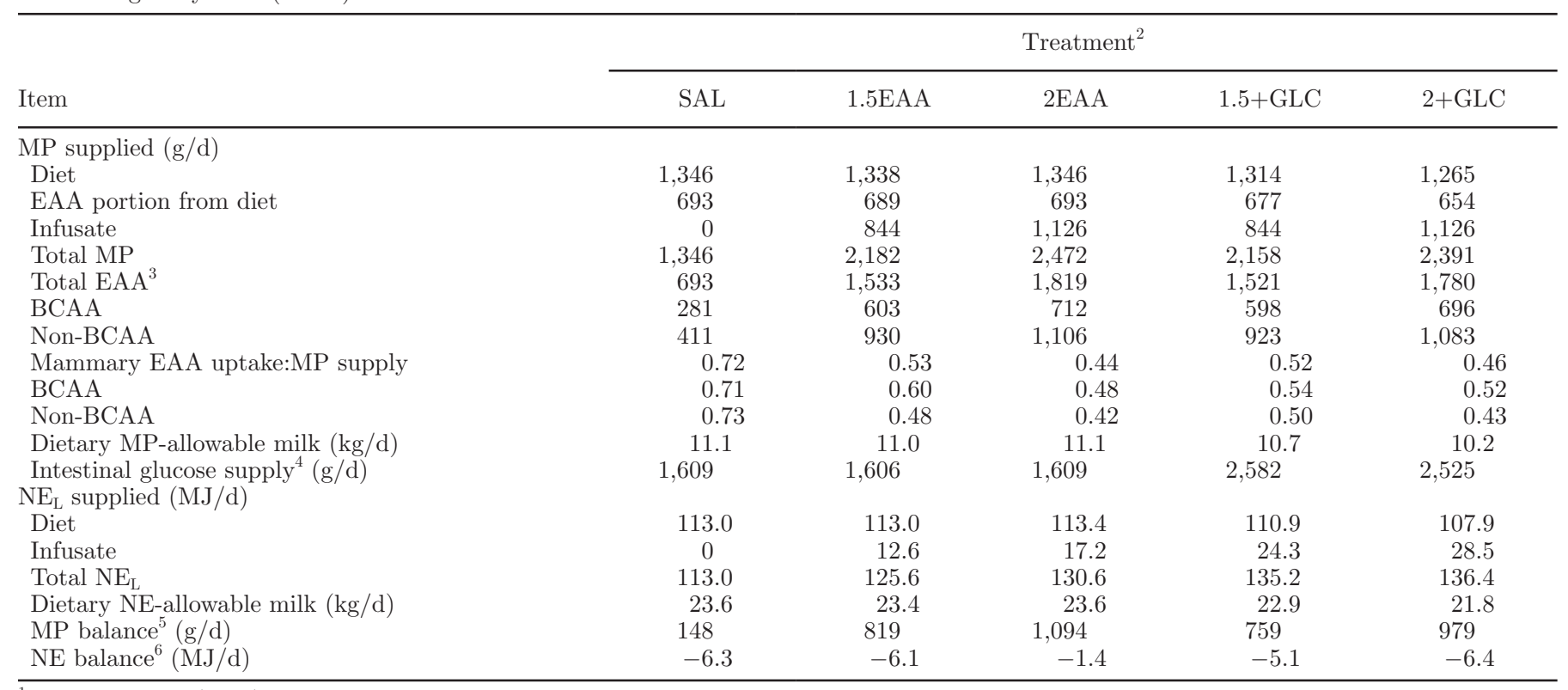

${ }^{1}$ Based on NRC (2001) calculations.

${ }^{2}$ Infusion treatments were $0.9 \%$ saline (SAL), or complete mixtures of EAA with the same profile and amount as found in 1,500 and $2,000 \mathrm{~g}$ of casein according to Metcalf et al. (1996), with or without the inclusion of $1 \mathrm{~kg}$ of glucose (1.5EAA, 2EAA, 1.5+GLC, and 2+GLC, respectively).

${ }^{3}$ EAA supplied by diet + infused EAA.

${ }^{4}$ Calculation uses resistant starch estimates from the CVB Table Ruminants (CVB, 2007) based on TMR ingredient composition.

${ }^{5}$ Calculation includes MP from diet + EAA infusates.

${ }^{6}$ Calculation includes energy from diet + EAA infusates.

both increased in response to infusion of a complete mix of AA, although synthesis was affected more, resulting in net AA gain. It is likely that a similar stimulation of protein synthesis and degradation in skeletal muscle occurred during EAA infusion, producing a net gain of protein, which reconciles the rise in circulating 3MHis concentration with the higher MP balance and the lower plasma NEAA concentrations.

Table 11. Estimated EAA availability for mammary and extra-mammary protein synthesis in lactating dairy cows from the basal diet at observed mean DMI and 5-d abomasal EAA and glucose (GLC) infusions

\begin{tabular}{|c|c|c|c|c|c|}
\hline \multirow[b]{2}{*}{ Item } & \multicolumn{5}{|c|}{ Treatment $^{1}$} \\
\hline & SAL & $1.5 \mathrm{EAA}$ & $2 \mathrm{EAA}$ & $1.5+\mathrm{GLC}$ & $2+\mathrm{GLC}$ \\
\hline Milk true protein yield (g/d) & 820 & 1,057 & 1,068 & 1,076 & 1,092 \\
\hline Diet-allowed milk protein yield ${ }^{2}(\mathrm{~g} / \mathrm{d})$ & 332 & 329 & 332 & 322 & 307 \\
\hline Milk protein difference $^{3}(\mathrm{~g} / \mathrm{d})$ & 488 & 728 & 736 & 754 & 785 \\
\hline Total EAA in milk protein ${ }^{4}(\mathrm{~g} / \mathrm{d})$ & 428 & 551 & 556 & 560 & 569 \\
\hline Infused EAA (g/d) & 0 & 844 & 1,126 & 844 & 1,126 \\
\hline \multicolumn{6}{|c|}{ Infused EAA not used for milk protein yield ${ }^{5}$} \\
\hline $\mathrm{g} / \mathrm{d}$ & $\mathrm{N} / \mathrm{A}$ & 465 & 743 & 452 & 717 \\
\hline$\%$ & $\mathrm{~N} / \mathrm{A}$ & 55 & 66 & 54 & 64 \\
\hline
\end{tabular}

${ }^{1}$ Infusion treatments were $0.9 \%$ saline (SAL), or complete mixtures of EAA with the same profile and amount as found in 1,500 and $2,000 \mathrm{~g}$ of casein according to Metcalf et al. (1996), with or without the inclusion of $1 \mathrm{~kg}$ of glucose (1.5EAA, 2EAA, 1.5+GLC, and 2+GLC, respectively). ${ }^{2}($ MP-allowable milk $\times 0.03) \times 1,000$.

${ }^{3}$ Milk true protein yield - diet-allowed milk protein yield.

${ }^{4}$ AA composition estimated from Mepham (1987).

${ }^{5}$ Infused EAA - EAA difference. 
Despite similar energy balances between SAL and EAA-infused cows, plasma NEFA concentration significantly increased with EAA. The lack of a treatment effect on plasma concentrations of lipid metabolites, acetate, and BHB suggests that fat mobilization from adipose was not affected but that catabolism of AA may have spared NEFA oxidation. Additionally, the lack of response in NEFA, acetate, and BHB uptake; the decrease in clearance of NEFA; and the increase in AA uptake and higher MUN concentration suggest the milk fat response in this study was supported by intramammary AA catabolism. A similar response was observed in dairy cows abomasally infused with casein where milk fat yield and MUN increased without a change in lipid precursor uptake by the mammary glands (Vanhatalo et al., 2003a).

\section{Glucose Effect on AA Partitioning}

When glucose was added to EAA infusions, DMI decreased approximately $1 \mathrm{~kg} / \mathrm{d}$, dietary MP supply decreased from 1,341 to $1,290 \mathrm{~g} / \mathrm{d}$, and $\mathrm{NE}_{\mathrm{L}}$ supply increased by $7.7 \mathrm{MJ} / \mathrm{d}$ (Table 10). Glucose did not stimulate milk protein production, leaving 54 and $64 \%$ of the 844 and 1,126 g/d of EAA infusate, respectively, that was not output into milk (Table 11).

Milk protein yield responses to provision of additional energy in the form of glucose, propionate, or acetate have been positive in some reports (Rulquin et al., 2004; Raggio et al., 2006a,b; Safayi and Nielsen, 2013), or nil in others (Vanhatalo et al., 2003b; Purdie et al., 2008; Curtis et al., 2014). When glucose was infused in this study, mammary uptakes of all AA groups were unaffected, including BCAA despite a decrease in arterial concentrations. The clearance of non-BCAA remained unchanged, in agreement with the level of milk protein synthesis during GLC infusion, but BCAA clearance increased suggesting their affinity for use by the gland changed with glucose supplementation. Mammary plasma flow was not affected by EAA or GLC infusions. Thus, it appears that when EAA are in abundant supply with or without glucose supplementation, mammary uptake of EAA is not affected by plasma concentrations or MPF after 5-d infusions, and is instead determined by AA-sequestering potential of mammary cells, which include processes of milk protein secretion and AA catabolism.

Whereas glucose had no effect on mammary utilization of AA groups, changes in milk urea and plasma AA concentrations suggest that glucose affected AA metabolism elsewhere. The decline in milk urea concentration indicates that AA catabolism was depressed during GLC infusion. Increased plasma concentration of the glucogenic AA Thr and Ser suggests that glu- coneogenesis from AA was suppressed during glucose supplementation in agreement with others who have found the same effect of postruminal glucose supplementation (Lemosquet et al., 2004).

Of the EAA in plasma, only the concentrations of BCAA significantly decreased as a result of GLC infusion. Many others have found a suppressive effect of glucose or insulin on AA concentrations in lactating cows, with the BCAA being most dramatically reduced (Clark et al., 1977; Mackle et al., 2000; Curtis et al., 2014), and it has been suggested that partitioning of BCAA into skeletal muscle could account for their lower plasma concentrations (Clark et al., 1977; Hurtaud et al., 1998; Curtis et al., 2014). The BCAA were infused at $431 \mathrm{~g} / \mathrm{d}$ on the $2 \mathrm{EAA}$ treatment, which elicited an increase in plasma BCAA concentration of $1,287 \mu \mathrm{M}$. Based on this rate:state relationship, the $401 \mu M$ decrease in BCAA due to glucose corresponds to a total BCAA efflux of $136 \mathrm{~g} / \mathrm{d}$. According to the BCAA content of bovine skeletal muscle (Early et al., 1990), 1.2 $\mathrm{kg} / \mathrm{d}$ of muscle protein could theoretically be synthesized from $136 \mathrm{~g} / \mathrm{d}$ BCAA. Whereas body protein loss from dairy cows between $14 \mathrm{~d}$ prepartum and 60 DIM ranges from 0.1 to $0.6 \mathrm{~kg} / \mathrm{d}$ (Komaragiri and Erdman, 1997; Phillips et al., 2003; Chibisa et al., 2008), Botts et al. (1979) reported repletion of $0.4 \mathrm{~kg} / \mathrm{d}$ of body protein when cows were re-fed a $22 \% \mathrm{CP}$ diet after consuming $9 \% \mathrm{CP}$ for 6 wk. Thus, $1.2 \mathrm{~kg}$ of net gain of muscle protein each day is double the highest reported rate of net loss or gain. However, whole-body protein synthesis based on Leu kinetics has been estimated at $3.7 \mathrm{~kg} / \mathrm{d}$ when mid lactation cows were fed a high-MP diet (Lapierre et al. 2002). The absence of a glucose effect on plasma 3M-His concentration indicates that skeletal muscle protein degradation was unaffected. Plasma insulin concentration increased with GLC, and in mature ruminants the anti-proteolytic action of insulin on muscle protein has been well demonstrated (Lobley, 1998). Euglycemic insulin administration to lactating goats decreased whole body proteolysis in one study (Tesseraud et al., 1993) and had no effect on hind limb protein degradation in another (Bequette et al., 2002), although net protein gains were increased in both. Hyperaminoacidemia did not affect the protein degradation or accretion responses to insulin in either of these studies (Tesseraud et al., 1993; Bequette et al., 2002).

The problem with attributing the observed decrease in BCAA concentrations to sequestration in a protein pool is the absence of a glucose effect on the other EAA in circulation. The BCAA in particular appear to be subject to faster utilization. Catabolism of the BCAA differs from the other $\mathrm{AA}$ in that it occurs less in the liver and more in peripheral tissues (Lapierre et al., 
2002), particularly in muscle and fat (Goodwin et al., 1987; Bergen et al., 1988). This segregation of catabolic pathways may allow BCAA to be differentially regulated so their plasma concentration would only decline if peripheral catabolism were upregulated. Branchedchain AA catabolism is initiated by the sequential actions of BCAT and BCKDH, the latter of which is deactivated by BCKDH-K (Brosnan and Brosnan, 2006). Infusion of EAA decreased abundance of BCKDH-K in longissimus dorsi, which remained elevated with GLC and is consistent with lower plasma concentration of BCAA during GLC infusion. However, BCAT1 mRNA expression in muscle tended to increase with EAA and decreased with GLC. Although these effects were not detected at the BCAT1 protein level, the depression in mRNA expression does not support the possibility that BCAA catabolism was upregulated in skeletal muscle during GLC infusion. Similarly, when infusion of the glucogenic precursor propionate stimulated milk protein yield in cows and caused plasma BCAA concentrations to fall, whole-body oxidation of labeled Leu to $\mathrm{CO}_{2}$ was not accelerated (Raggio et al., 2006b).

The decreases in acetate, BHB, and NEFA concentrations in plasma in response to GLC infusion indicate that adipose lipogenesis was stimulated, as expected from the insulin response (Eisemann and Huntington, 1994; Rigout et al., 2002; Lemosquet et al., 2009). Recent work demonstrates that plasma BCAA concentrations decrease as much as NEFA during glucose tolerance tests and that obesity and insulin resistance states reduce the magnitude of NEFA and BCAA responses to insulin equally (Shaham et al., 2008; Geidenstam et al., 2013). From flux of Val through BCKHD in explants, Herman et al. (2010) estimated that adipose tissue of mice could catabolize $950 \mathrm{nmol}$ of BCAA/h, compared with $830 \mathrm{nmol} / \mathrm{h}$ in skeletal muscle. Branched-chain $\alpha$-keto acids decarboxylated by BCKDH can serve as primers for de novo fatty acid synthesis by fatty acid synthase in adipose (Su et al., 2015), so effects of insulin on adipose lipogenesis would preferentially affect concentrations of BCAA in plasma in conjunction with other lipogenic precursors. In support of a role for adipose tissue in BCAA utilization, transplantation of adipose tissue from wild-type mice into BCAT2 knockout littermates caused plasma BCAA concentrations to fall (Herman et al., 2010). Although many studies report decreases in plasma BCAA with glucose or insulin infusion (Mackle et al., 2000; Bequette et al., 2001; Curtis et al., 2014), the only study of BCAA metabolism in ruminant adipose tissue of which we are aware showed that BCAA-C was incorporated into fatty acids by adipose tissue from adult sheep in vitro at $2.8 \%$ of the rate that acetate-C was used (Vernon et al., 1985). In our study, the absence of an effect of GLC on expression of the enzymes of BCAA catabolism in muscle supports adipose tissue as the preferential fate of BCAA efflux during glucose supplementation.

\section{CONCLUSIONS}

This study demonstrates stimulation of milk protein synthesis in response to 5-d EAA and glucose supplementation in lactating dairy cows. The addition of glucose to EAA infusate did not stimulate greater milk protein yield, but did decrease MUN and plasma BCAA, while stimulating skeletal muscle accretion via increased insulin signaling. These results suggest that although milk protein yield is not stimulated further with postruminal energy supplementation when EAA are not limiting for milk protein synthesis, surplus AA are spared from gluconeogenesis and catabolism and may be directed toward extra-mammary tissues leading to improved $\mathrm{N}$ retention in the body and lower $\mathrm{N}$ loss into milk. Additionally, there may be a limit to the synthetic capacity of mammary cells after 5 -d infusions if a surplus of milk protein precursor plus energy supply does not promote an unlimited response in protein yield. Furthermore, these results support the preferential use of BCAA in adipose metabolism in glucose-supplemented lactating cows when EAA are in abundant supply.

\section{ACKNOWLEDGMENTS}

The authors gratefully acknowledge the dairy barn staff at Trouw Nutrition Agresearch Canada. Financial support was provided by Trouw Nutrition Agresearch Canada (Guelph, ON, Canada), and NSERC Canada (Ottawa, ON, Canada).

\section{REFERENCES}

Appuhamy, J. A. D. R. N., J. R. Knapp, O. Becvar, J. Escobar, and M. D. Hanigan. 2011. Effects of jugular-infused lysine, methionine, and branched-chain amino acids on milk protein synthesis in highproducing dairy cows. J. Dairy Sci. 94:1952-1960.

Bequette, B. J., C. E. Kyle, L. A. Crompton, S. E. Anderson, and M. D. Hanigan. 2002. Protein metabolism in lactating goats subjected to the insulin clamp. J. Dairy Sci. 85:1546-1555.

Bequette, B. J., C. E. Kyle, L. A. Crompton, V. Buchan, and M. D. Hanigan. 2001. Insulin regulates milk production and mammary gland and hind-leg amino acid fluxes and blood flow in lactating goats. J. Dairy Sci. 84:241-255.

Bergen, W. G., J. R. Busboom, and R. A. Merkel. 1988. Leucine degradation in sheep. Br. J. Nutr. 59:323-333.

Blum, J. W., T. Reding, F. Jans, M. Wanner, M. Zemp, and K. Bachmann. 1985. Variations of 3- Methylhistidine in blood of dairy cows. J. Dairy Sci. 68:2580-2587.

Boogers, I., W. Plugge, Y. Q. Stokkermans, and A. L. L. Duchateau. 2008. Ultra-performance liquid chromatographic analysis of amino acids in protein hydrolysates using an automated pre-column derivatisation method. J. Chromatogr. A 1189:406-409. 
Botts, R. L., R. W. Hemken, and L. S. Bull. 1979. Protein reserves in the lactating dairy cow. J. Dairy Sci. 62:433-440.

Brosnan, J. T., and M. E. Brosnan. 2006. Branched-chain amino acids: Enzyme and substrate regulation. J. Nutr. 136:207S-211S.

Bucolo, G., and H. David. 1973. Quantitative determination of serum triglycerides by the use of enzymes. Clin. Chem. 19:476-482.

Canadian Council on Animal Care. 2009. Guidelines on the care and use of farm animals in research, teaching and testing. Canadian Council on Animal Care, Ottawa, ON, Canada.

Cant, J. P., R. Berthiaume, H. Lapierre, P. H. Luimes, B. W. McBride, and D. Pacheco. 2003. Responses of the bovine mammary glands to absorptive supply of single amino acids. Can. J. Anim. Sci. 83:341-355.

Cant, J. P., E. J. DePeters, and R. L. Baldwin. 1993. Mammary uptake of energy metabolites in dairy cows fed fat and its relationship to milk protein depression. J. Dairy Sci. 76:2254-2265.

Chibisa, G. E., G. N. Gozho, A. G. Van Kessel, A. A. Olkowski, and T. Mutsvangwa. 2008. Effects of peripartum propylene glycol supplementation on nitrogen metabolism, body composition, and gene expression for the major protein degradation pathways in skeletal muscle in dairy cows. J. Dairy Sci. 91:3512-3527.

Clark, J. H., H. R. Spires, R. G. Derrig, and M. R. Bennink. 1977. Milk production, nitrogen utilization and glucose synthesis in lactating cows infused postruminally with sodium caseinate and glucose. J. Nutr. 107:631-644.

Curtis, R. V., J. J. M. Kim, D. L. Bajramaj, J. Doelman, V. R. Osborne, and J. P. Cant. 2014. Decline in mammary translational capacity during intravenous glucose infusion into lactating dairy cows. J. Dairy Sci. 97:430-438.

CVB (Centraal Veevoederbureau). 2007. CVB Table Ruminants 2007, series nr. 32. CVB, The Hague, the Netherlands.

DePeters, E. J., and J. D. Ferguson. 1992. Nonprotein nitrogen distribution in the milk of cows. J. Dairy Sci. 75:3192-3209.

Doelman, J., R. V. Curtis, M. Carson, J. J. M. Kim, J. A. Metcalf, and J. P. Cant. 2015a. Essential amino acid infusions stimulate mammary expression of eukaryotic initiation factor $2 \mathrm{~B} \varepsilon$ but milk protein yield is not increased during an imbalance. J. Dairy Sci. 98:4499-4508.

Doelman, J., J. J. M. Kim, M. Carson, J. A. Metcalf, and J. P. Cant. 2015b. Branched-chain amino acid and lysine deficiencies exert different effects on mammary translational regulation. J. Dairy Sci. 98:7846-7855.

Doepel, L., and H. Lapierre. 2010. Changes in production and mammary metabolism of dairy cows in response to essential and nonessential amino acid infusions. J. Dairy Sci. 93:3264-3274.

Early, R. J., B. W. McBride, and R. O. Ball. 1990. Growth and metabolism in somatotropin-treated steers: III. Protein synthesis and tissue expenditures. J. Anim. Sci. 68:4153-4166.

Eisemann, J. H., and G. B. Huntington. 1994. Metabolite flux across portal-drained viscera, liver, and hindquarters of hyperinsulinemic, euglycemic beef steers. J. Anim. Sci. 72:2919-2929.

Galindo, C. E., D. R. Ouellet, D. Pellerin, S. Lemosquet, I. OrtiguesMarty, and H. Lapierre. 2011. Effect of amino acid or casein supply on whole-body, splanchnic, and mammary glucose kinetics in lactating dairy cows. J. Dairy Sci. 94:5558-5568.

Geidenstam, N., P. Spégel, H. Mulder, K. Filipsson, M. Ridderstråle, and A. P. H. Danielsson. 2013. Differences in the metabolic response to an oral glucose tolerance test between adult lean and obese individuals. Diabetologia 56(Suppl. 1):642.

Gietzen, D. W. 1993. Neural mechanisms in the responses to amino acid deficiency. J. Nutr. 123:610-625.

Goodwin, G. W., W. Gibboney, R. Paxton, R. A. Harris, and J. A. Lemons. 1987. Activities of branched-chain amino acid aminotransferase and branched-chain 2-oxo acid dehydrogenase complex in tissues of maternal and fed sheep. Biochem. J. 242:305-308.

Griinari, J. M., M. A. McGuire, D. A. Dwyer, D. E. Bauman, D. M. Barbano, and W. A. House. 1997. The role of insulin in the regulation of milk protein synthesis in dairy cows. J. Dairy Sci. 80:2361-2371.
Hanigan, M. D., J. P. Cant, D. C. Weakley, and J. L. Beckett. 1998a. An evaluation of postabsorptive protein and amino acid metabolism in the lactating dairy cow. J. Dairy Sci. 81:3385-3401.

Hanigan, M. D., J. Dijkstra, W. J. J. Gerrits, and J. France. 1997. Modelling post-absorptive protein and amino acid metabolism in the ruminant. Proc. Nutr. Soc. 56:631-643.

Hanigan, M. D., J. France, D. Wray-Cahen, D. E. Beever, G. E. Lobley, L. Reutzel, and N. E. Smith. 1998b. Alternative models for analyses of liver and mammary transorgan metabolite extraction data. Br. J. Nutr. 79:63-78.

Herman, M. A., P. She, O. D. Peroni, C. J. Lynch, and B. B. Kahn. 2010. Adipose tissue branched chain amino acid (BCAA) metabolism modulates circulating BCAA levels. J. Biol. Chem. 285:11348-11356.

Hurtaud, C., S. Lemosquet, and H. Rulquin. 2000. Effect of graded duodenal infusions of glucose on yield and composition of milk from dairy cows. 2. Diets based on grass silage. J. Dairy Sci 83:2952-2962.

Hurtaud, C., H. Rulquin, and R. Verite. 1998. Effects of graded duodenal infusions of glucose on yield and composition of milk from dairy cows. 1. Diets based on corn silage. J. Dairy Sci. 81:3239-3247.

Komaragiri, M. V. S., and R. A. Erdman. 1997. Factors affecting body tissue mobilization in early lactation dairy cows. 1. Effect of dietary protein on mobilization of body fat and protein. J. Dairy Sci. 80:929-937.

Lapierre, H., J. P. Blouin, J. F. Bernier, C. K. Reynolds, P. Dubreuil, and G. E. Lobley. 2002. Effect of supply of metabolizable protein on whole body and splanchnic leucine metabolism in lactating dairy cows. J. Dairy Sci. 85:2631-2641.

Lemosquet, S., G. Raggio, G. E. Lobley, H. Rulquin, J. Guinard-Flament, and H. Lapierre. 2009. Whole-body glucose metabolism and mammary energetic nutrient metabolism in lactating dairy cows receiving digestive infusions of casein and propionic acid. J. Dairy Sci. 92:6068-6082.

Lemosquet, S., S. Rigout, A. Bach, H. Rulquin, and J. W. Blum. 2004. Glucose metabolism in lactating cows in response to isoenergetic infusions of propionic acid or duodenal glucose. J. Dairy Sci. 87:1767-1777.

Livak, K. J., and T. D. Schmittgen. 2001. Analysis of relative gene expression data using real-time quantitative PCR and the $2^{-\triangle \Delta C T}$ method. Methods 25:402-408.

Lobley, G. E. 1998. Nutritional and hormonal control of muscle and peripheral tissue metabolism in farm species. Livest. Prod. Sci. 56:91-114.

Mackle, T. R., D. A. Dwyer, K. L. Ingvertsen, P. Y. Chouinard, D. A. Ross, and D. E. Bauman. 2000. Effects of insulin and postruminal supply of protein on use of amino acids by the mammary gland of milk protein synthesis. J. Dairy Sci. 83:93-105.

Mepham, T. B. 1987. Physiology of Lactation. Open University Press, Milton Keynes, UK.

Metcalf, J. A., L. A. Crompton, D. Wray-Cahen, M. A. Lomax, J. D. Sutton, D. E. Beever, J. C. MacRae, B. J. Bequette, F. R. C. Backwell, and G. E. Lobley. 1996. Responses in milk constituents to intravascular administration of two mixtures of amino acids to dairy cows. J. Dairy Sci. 79:1425-1429.

NRC. 2001. Nutrient Requirements of Dairy Cattle. 7th rev. ed. Natl. Acad. Sci., Washington, DC.

Phillips, G. J., T. L. Citron, J. S. Sage, K. A. Cummins, M. J. Cecava, and J. P. McNamara. 2003. Adaptations in body muscle and fat in transition dairy cattle fed differing amounts of protein and methionine hydroxyl analog. J. Dairy Sci. 86:3634-3647.

Purdie, N. G., D. R. Trout, D. P. Poppi, and J. P. Cant. 2008. Milk synthetic response of the bovine mammary gland to an increase in the local concentration of amino acids and acetate. J. Dairy Sci. 91:218-228.

Raggio, G., S. Lemosquet, G. E. Lobley, H. Rulquin, and H. Lapierre. 2006a. Effect of casein and propionate supply on mammary protein metabolism in lactating dairy cows. J. Dairy Sci. 89:4340-4351.

Raggio, G., G. E. Lobley, S. Lemosquet, H. Rulquin, and H. Lapierre. 2006b. Effect of casein and propionate supply on whole body 
protein metabolism in lactating dairy cows. Can. J. Anim. Sci. $86: 81-89$.

Rigout, S., S. Lemosquet, A. Bach, J. W. Blum, and H. Rulquin. 2002. Duodenal infusion of glucose decreases milk fat production in grass silage-fed dairy cows. J. Dairy Sci. 85:2541-2550.

Rius, A. G., M. L. McGilliard, C. A. Umberger, and M. D. Hanigan. 2010. Interactions of energy and predicted metabolizable protein in determining nitrogen efficiency in the lactating dairy cow. J. Dairy Sci. 93:2034-2043.

Rulquin, H., S. Rigout, S. Lemosquet, and A. Bach. 2004. Infusion of glucose directs circulating amino acids to the mammary gland in well-fed dairy cows. J. Dairy Sci. 87:340-349.

Safayi, S., and M. O. Nielsen. 2013. Intravenous supplementation of acetate, glucose or essential amino acids to an energy and protein deficient diet in lactating dairy goats: Effects on milk production and mammary nutrient extraction. Small Rumin. Res. 112:162173.

Shaham, O., R. Wei, T. J. Wang, C. Ricciardi, G. D. Lewis, R. S. Vasan, S. A. Carr, R. Thadhani, R. E. Gerszten, and V. K. Mootha. 2008. Metabolic profiling of the human response to a glucose challenge reveals distinct axes of insulin sensitivity. Mol. Syst. Biol. $4: 214$.
Su, X., F. Magkos, D. Zhou, J. C. Eagon, E. Fabbrini, A. L. Okunade, and S. Klein. 2015. Adipose tissue monomethyl branched-chain fatty acids and insulin sensitivity: Effects of obesity and weight loss. Obesity (Silver Spring) 23:329-334.

Tesseraud, S., J. Grizard, E. Debras, I. Papet, Y. Bonnet, G. Bayle, and C. Champredon. 1993. Leucine metabolism in lactating and dry goats: Effect of insulin and substrate availability. Am. J. Physiol. 265:E402-E413.

Tyrrell, H. F., and J. T. Reid. 1965. Prediction of the energy value of cow's milk. J. Dairy Sci. 48:1215-1223.

Vanhatalo, A., T. Varvikko, and P. Huhtanen. 2003a. Effects of various glucogenic sources on production and metabolic responses of dairy cows fed grass silage-based rations. J. Dairy Sci. 86:3249-3259.

Vanhatalo, A., T. Varvikko, and P. Huhtanen. 2003b. Effects of casein and glucose on responses of cows fed diets based on restrictively fermented grass silage. J. Dairy Sci. 86:3260-3270.

Vernon, R. G., E. Finley, and E. Taylor. 1985. Fatty acid synthesis from amino acids in sheep adipose tissue. Comp. Biochem. Physiol. B 82:133-136.

Weekes, T. L., P. H. Luimes, and J. P. Cant. 2006. Responses to amino acid imbalances and deficiencies in lactating dairy cows. J. Dairy Sci. 89:2177-2187. 